\title{
Export promotion programs: Their impact on companies' internationalization performance and competitiveness
}

\author{
Joan Freixanet* \\ ESCI - Universidad Pompeu Fabra, Business Strategy, Pg. Pujades, 1, 08003 Barcelona, Spain
}

A R T I C L E I N F O

\section{Article history:}

Received 27 December 2010

Received in revised form 5 December 2011

Accepted 5 December 2011

\section{Keywords:}

Export promotion

Impact evaluation

Internationalization

Programs

Small to medium-sized enterprises

\section{Introduction}

Economic globalization and the increasing flow of merchandise, services and capital imply not only new opportunities but also new challenges for companies. In this context of opening borders and the increase in international trade, many enterprises, especially small- to medium-sized ones, do not make the most of all of the potential of foreign markets because of a lack of motivation, capabilities and/or human or financial resources. A whole set of services have been created, offered both through public and private initiatives, with the aim of helping companies to overcome these obstacles.

In the last two decades, these export promotion programs (EPPs) have increased their number and weight in governments' budgets. However, this evolution has not been followed by an equal amount of research in this area.

The need for further investigation has been emphasized by different authors. These authors explicitly point out the necessity of synthesizing the different research and obtaining more generalizable results (Gray, 1997; Katsikeas, Piercy, \& Ioannidis, 1996), further demonstrating the relationship between program use and export performance (Brouthers \& Wilkinson, 2000; Gençtürk \& Kotabe, 2001), or undertaking more methodologically consistent research (for example, Diamantopoulos, Schlegelmilch, \& Tse, 1993; Gillespie \& Riddle, 2004; Seringhaus, 1986).

Thus far, the success of EPPs has been only partially evaluated. Specifically, this is to our knowledge the first study that evaluates the collective effects of EPPs in export performance, considering a variety of impact dimensions, while differentiating the individual effects of each program.

It is also one of the rare studies to include a broad representation of companies from a variety of industries and levels of export involvement.

\footnotetext{
* Tel.: +34 626823722.

E-mail address: jfreixanets@uoc.edu.
} 
There are several important motivations for carrying out a thorough and rigorous evaluation of EPPs. The first motivation is the need to help export promotion organizations (EPOs) to improve program design, adapt programs to company requirements and create better implementation procedures. The second motivation is the importance of increasing EPPs' credibility in the eyes both of public opinion and of governments, which ultimately finance export promotion. Finally it is necessary to give company managers information about the role programs can play in their organizations.

\section{Literature review}

Different studies have been carried out to evaluate EPPs. In this paper they are analyzed looking at both their content and their methodology (see Appendix A for a complete list and summary of previous studies).

As to the content, we find on one hand articles on theoretical development and methodology. It is worth highlighting the contributions by Gillespie and Riddle (2004) and Diamantopoulos et al. (1993), which analyze the role of EPOs and make some methodological recommendations for the preparation of empirical research.

On the other hand, regarding empirical studies, we find in the first place macroeconomic, aggregate, quantitative evaluations (Armah \& Epperson, 1997; Knowles \& Mathur, 1997; Onunkwo \& Epperson, 2000). Their objective is to measure the global impact of specific promotion interventions, and they are mostly centered in the food industry (e.g. Armah and Epperson's study on the impact of export promotion on the demand of American concentrated orange juice from the European Union and Japan; it was concluded that investment in EPPs is clearly compensated by the increase in exports). This type of approach has been criticized because of the difficulty in inferring valid conclusions given the high number of variables intervening in the export performance of a country or region.

Increasing attention has since been dedicated to the effects of export promotion programs in companies. An important part of these studies has focused on evaluating only specific programs (Spence, 2003; Brouthers \& Wilkinson, 2006, Davar \& Wheeler, 1992, and others). The most frequently considered is the use of sponsored foreign trade shows. Other programs evaluated are trade missions, foreign trade offices, and information programs.

Another group involving more ambitious research has looked at the performance of programs collectively.

The first approach has been a cost-benefit analysis of the export support system (Layard, 1974; Pointon, 1978; Williams, 1973; Wills \& Oldman, 1975).

Another more recent line of study has focused on the evaluation of the degree of the programs' adaptation to company needs (Crick, 1995; Czinkota \& Kotabe, 1992; Czinkota \& Ricks, 1981; Naidu \& Rao, 1993). The objective of this group of studies is to determine to what extent the design of programs corresponds to the real needs of exporters.

Complementarily, often research has evaluated the general perception of usefulness of the programs (Clarke, 1991, and others); or the differences in this perception depending on the managers' ethnical origin (Crick \& Chaudhry, 2000).

Another type of measurement regards the degree of awareness and use of the programs as a measure of their success (for example Pahud de Mortanges \& Van Gent, 1991).

Some studies have indirectly evaluated program effects, considering them among otherfactors to explain export performance (Crick and Chaudhry, 1997; Katsikeas et al., 1996; Walters, 1983).

Finally, Gençtürk and Kotabe (2001), Francis and Collins-Dodd (2004), and Calderón and Fayos (2004) have measured EPPs' effects using different performance outcomes.

The analyzed studies' conclusions are mixed: some of them find that the programs have a positive effect, while others do not.

Thus, some research states that programs play an important role in helping companies overcome internationalization barriers (Czinkota \& Ricks, 1981; Seringhaus \& Mayer, 1988); programs enable the acquisition of knowledge related to export decision making (Brooks \& Rosson, 1982; Lee \& Brasch, 1978; Suntook, 1978); or locating sales leads in less time (Seringhaus, 1984).

For example, three out of four companies in the sample used by Cullwick and Mellallieu (1981) answered that export assistance was useful in the medium or long term. More specifically, in an analysis of 367 firms that had participated in sponsored trade shows, Seringhaus and Rosson (1991) concluded that this program resulted in more than \$350 million in sales for participating companies, and that the return for each dollar of public expenditure was \$28. Coughlin and Cartwright (1987) estimated an increase in exports of $\$ 432$ for each dollar spent in export assistance.

However, other studies show that there is a mismatch between company needs and government assistance priorities, based on managers' perceptions (Czinkota, 1982; Seringhaus \& Botschen, 1991; Seringhaus \& Rosson, 1990); that there is no clear relationship between programs and export performance (Cunningham \& Spigel, 1971; Gronhaug \& Lorentzen, 1983); or that companies have little awareness of programs altogether and do not use them (Chokar \& Kedia, 1986).

For instance, Martin (1996) found no relationship between the existence of State export promotional offices in Japan and export volume to this country; Crick and Czinkota (1995) concluded that managers do not perceive the governments' assistance as positive; Albaum (1983) that companies do not find EPPs useful; and Reid (1984) observed that only $44 \%$ of Canadian companies were aware of the programs.

The reason for these opposite conclusions may be due to difficulties related to measuring and comparing the impact of the export promotion programs. The difficulties are mainly the following:

- The differences in the export performance outcomes as operationalized in various studies: some of the studies oriented to intermediate results and others oriented to final results; additionally, the studies used diverse industries and company types. 
- The necessary time lag between the start of the program and the materialization of its effects.

- The number of variables that affect export performance and that may counteract programs' effects.

- The content and objectives of each program may be very different, and therefore a global evaluation can prevent the detection of differences that may be important.

To overcome these difficulties, several methodological recommendations have been made. They can be summarized as follows:

- The use of multidimensional performance outcomes that consider both managers' perceptions and objective results (Czinkota, 1996; Diamantopoulos et al., 1993; Gençtürk \& Kotabe, 2001; Katsikeas et al., 1996).

- The use of contrast groups consisting of samples stratified ex ante with enough companies representing different typologies: industry, size or internationalization involvement (Brouthers \& Wilkinson, 2000; Katsikeas et al., 1996; Seringhaus, 1986).

- The differentiation of the different EPPs and organizations (Naidu \& Rao, 1993; Pointon, 1978).

- Obtaining time-series data with a long enough time lag (longitudinal studies) (Gray, 1997; Seringhaus \& Rosson, 1990).

As shown in Table 1, these methodological recommendations have been followed only partially in previous studies. Specifically:

- Most of the studies are cross-sectional.

- It is necessary to increase the multidimensionality of outcomes used, which complement the economic indicators, with those related to strategy and managers' perceptions.

- Less than half of the studies use contrast groups, and few of these use significant samples stratified ex ante.

- Most of the studies do not evaluate EPPs both collectively and individually.

- None of the analyzed studies comply with all of the methodological recommendations at the same time.

Given the importance of the methodological issues they were all taken into consideration in this study. ${ }^{1}$

Regarding the unit of analysis, which is considered by Katsikeas, Leonidou, and Morgan (2000) to be a critical element in the scope of studies on export performance, this study uses the firm rather than carrying out an aggregate macroeconomic evaluation (for the reasons explained earlier in this section) or focusing on managers (as in Gray, 1997). Although analyzing employees' features in terms of their attitudes and skills is interesting given that they are the people who use EPPs, this approach has been used rarely either by researchers or by EPOs. One of the main reasons for this lies in the difficulty of finding, checking and classifying objective data that relates to managers, while company information is more reliable and verifiable.

\section{Segmentation and hypothesis}

The level of the company's international involvement, which is understood to be the degree of commitment to foreign markets, is the most widely used segmentation variable in the research on export assistance.

Numerous studies suggest that the stage of export involvement directly affects the relationship between program use, company international decisions and export performance (Alonso \& Donoso, 1996; Cavusgil, 1983; Crick, 1997; Czinkota, 1982; Diamantopoulos et al., 1993; Francis \& Collins-Dodd, 2004; Gençtürk \& Kotabe, 2001; Luostarinen \& Welch, 1988; Naidu \& Rao, 1993; Olson, 1975; Pahud de Mortanges \& Van Gent, 1991; Samiee \& Walters, 1990).

Other classification variables that previously have not been widely used are company size, industry, nationality (a variable proposed by Cavusgil, 1983 or Dichtl, Koeglmayr, \& Muller, 1986), and even managers' ethnic origin (in Crick \& Chaudhry, 2000).

Most of the above variables were considered and tested in this study. Classifying companies by industry also provided interesting results, although there was a high heterogeneity within groups regarding aspects such as size and international experience, which would make it difficult to extract conclusions regarding program design. Therefore, and although we believe EPP impact by industry is a topic which deserves further analysis, in this study companies were segmented by export involvement, because both previous research and EPP analysis show that this is the critical factor when designing appropriate programs. Indeed, the assistance needs of a company starting to export will differ from a company already exporting and trying to diversify its markets; the needs of a company starting to export also will differ from those of a multinational company that has production subsidiaries in several countries. These differences should be taken into consideration when designing the programs.

\footnotetext{
${ }^{1}$ This study deals with the recommendation to obtain time-series data by taking the export volume three and five years before the year of study $(n-3$ and $n-5$ ) and then calculating export growth. Obtaining the data for different years for the rest of the outcomes and thus developing a complete longitudinal analysis, is one avenue for future research (Section 7).
} 
Table 1

Studies on export promotion and methodological issues.

\begin{tabular}{|c|c|c|c|c|c|}
\hline Author & $\mathrm{C}$ & $\mathrm{S}$ & $\mathrm{O}$ & $\mathrm{D}$ & $\mathrm{L}$ \\
\hline \multicolumn{6}{|l|}{ Brewer (2009) } \\
\hline \multicolumn{6}{|l|}{ Brouthers and Wilkinson (2006) } \\
\hline \multicolumn{6}{|l|}{ Wilkinson (2006) } \\
\hline Francis and Collins-Dodd (2004) & Ex post & & & & \\
\hline Gillespie and Riddle (2004) & - & - & - & - & - \\
\hline \multicolumn{6}{|l|}{ Calderón and Fayos (2004) } \\
\hline \multicolumn{6}{|l|}{ Spence (2003) } \\
\hline Gençtürk and Kotabe (2001) & Ex post & & & & \\
\hline \multicolumn{6}{|l|}{ Duran and Ubeda (2001) } \\
\hline \multicolumn{6}{|l|}{ Brouthers and Wilkinson (2000) } \\
\hline Crick and Chaudhry (2000) & Ex post & & & & \\
\hline Seringhaus and Rosson (1998) & Ex ante & & & & \\
\hline Gray (1997) & Ex post & & & & \\
\hline Crick and Chaudhry (1997) & Ex post & & & & \\
\hline Katsikeas et al. (1996) & Ex Post & & & & \\
\hline Crick (1995) & Ex ante & & & & \\
\hline Crick and Czinkota (1995) & Ex post & & & & \\
\hline Singer and Czinkota (1994) & Ex post & & & & \\
\hline Diamantopoulos et al. (1993) & - & - & - & - & - \\
\hline Naidu and Rao (1993) & Ex post & & & & \\
\hline $\begin{array}{l}\text { Diamantopoulos, Schlegelmilch, } \\
\text { and Inglis (1991) }\end{array}$ & Ex post & & & & \\
\hline \multicolumn{6}{|l|}{ Seringhaus and Botschen (1991) } \\
\hline Seringhaus and Mayer (1988) & Ex ante & & & & \\
\hline Seringhaus (1987) & Ex ante & & & & \\
\hline \multicolumn{6}{|l|}{ Lemaghen (1987) } \\
\hline Chokar and Kedia (1986) & Ex ante & & & & \\
\hline \multicolumn{6}{|l|}{ Seringhaus (1986). The Impact. . . } \\
\hline Seringhaus (1986) & Ex ante & & & & \\
\hline Seringhaus (1984) & Ex ante & & & & \\
\hline \multicolumn{6}{|l|}{ Reid (1984) } \\
\hline \multicolumn{6}{|l|}{ Walters (1983) } \\
\hline \multicolumn{6}{|l|}{ Singh (1983) } \\
\hline \multicolumn{6}{|l|}{ Buckley (1983, chap. 4) } \\
\hline \multicolumn{6}{|l|}{ Brezzo and Perkal (1983, chap. 4) } \\
\hline Albaum (1983) & Ex ante & & & & \\
\hline Czinkota (1982) & Ex ante & & & & \\
\hline Czinkota (1982). An Evaluation. . & Ex post & & & & \\
\hline $\begin{array}{l}\text { Schwarting, Thoben, } \\
\text { and Wittstock (1982) }\end{array}$ & Ex ante & & & & \\
\hline \multicolumn{6}{|l|}{ Czinkota and Ricks (1981) } \\
\hline \multicolumn{6}{|l|}{ Cullwick and Mellallieu (1981) } \\
\hline Welch and Wiedersheim-Paul (1979) & Ex post & & & & \\
\hline Pointon (1978) & Ex post & & & & \\
\hline \multicolumn{6}{|l|}{ Gronhaug and Lorentzen (1983) } \\
\hline Mayer and Flynn (1973) & & & & & \\
\hline
\end{tabular}

C: use of contrast groups which enable result comparisons. O: measurement of impact through Objective indicators. S: measurement of impact through Subjective indicators. D: differentiation of the EPPs. L: longitudinal data.

Shadowed portions indicate the study complies with the methodological recommendation in that column.

Although most previous studies have allowed companies to self-assign their export stage, we decided to classify the companies using our own explicit and reasoned criteria, to provide a more consistent and objective segmentation procedure.

The variables selected for classification were as follows: export volume, size of the export or international expansion department (number of employees working in international business), existence of permanent establishments abroad (branch office or subsidiaries), and production abroad (availability of production subsidiaries).

These variables were selected because they complement each other in indicating the level of involvement and skills regarding internationalization, the two main attributes that determine the evolution through the different internationalization stages. A further explanation follows:

- Export volume: many studies suggest that the amount of sales in foreign markets is one of the main indicators of the level of a company's international involvement. To achieve these sales companies must invest in production infrastructure, personnel, inventory, marketing, etc. Therefore, the level of exports is related to the importance of the commitment of resources for the international markets; also, more skills will usually be needed to achieve and maintain these international sales.

- Size of the export or international expansion department: this classification variable relates to the previous one. A higher number of employees working in international business implies a higher commitment of resources for the export 
Table 2

Classification criteria by internationalization stage, based on the level of involvement with foreign markets.

\begin{tabular}{|c|c|c|c|c|}
\hline Stage & $\begin{array}{l}\text { Exports } \\
(€ \mathrm{~m})\end{array}$ & $\begin{array}{l}\text { Permanent } \\
\text { establishments }\end{array}$ & $\begin{array}{l}\text { Employees export } \\
\text { department }\end{array}$ & $\begin{array}{l}\text { Internationalization } \\
\text { involvement/skills }\end{array}$ \\
\hline 1. Starting/passive exporter & $1-99$ & NO & & Low \\
\hline 2. Regular exporter with little structure & $>300$ & NO & $\leq 3$ & Low-Medium \\
\hline 3. Regular exporter with complete structure & $>300$ & NO & $>3$ & Medium \\
\hline $\begin{array}{l}\text { 4. Consolidated exporter with permanent } \\
\text { sales or logistic establishments }\end{array}$ & $>2500$ & YES & $>3$ & High \\
\hline $\begin{array}{l}\text { 5. Industrial multinational with } \\
\text { production subsidiaries abroad }\end{array}$ & $>2500$ & YES & $>3$ & Very high \\
\hline
\end{tabular}

department (increase in salaries, travelling expenses, office space, etc.). As suggested by different authors (Cavusgil, 1983; Gray, 1997; Reid, 1984), skills will also increase with more professionals contributing their knowledge, experience and efforts to internationalization.

- Creation of permanent establishments abroad (branch offices or sales subsidiaries): this variable implies a further step in a company's internationalization, since it entails investing in personnel, legal formalities, renting or buying the business premises. . It also raises exit barriers, making it more difficult giving up internationalization. Furthermore, it implies the company will have to develop a set of skills (international management, adaptation to different legal environments...), which is wider than the one from exporters which have not created permanent establishments.

- Creation of a production subsidiary: all the factors of international involvement related to sales establishments are enhanced when a production subsidiary is created. The firm must invest not only in the sales area but also in the rest of the departments (technicians, managers, production employees, machinery, inventory, etc.). Significant exit barriers are thus created, and consequently, producing abroad is a decisive step in the company's internationalization. Moreover, using this entry form implies that extensive information is needed on topics such as the tax or labor legal system, the law regarding foreign investment, logistics inside the country and with the company's country, etc. The firm will, therefore, develop a set of more advanced skills than those of companies in the previous stages (Barret \& Wilkinson, 1986).

According to these criteria, companies were segmented ex ante into 5 stages, as shown in Table $2 .^{2}$

In our model, programs and performance outcomes have been classified into different groups. This classification is based on the fact that programs usually aim to support a variety of factors, either in terms of increase in competitiveness, strategic position or economic results. Logically, programs share some common objectives, and therefore a hypothesis may be formulated in terms of several programs and outcomes. This hypothesizing is also justified because a single program alone cannot alone foster all of the intermediate results that may bring about export performance.

Thus, we examine the impact, by each internationalization stage, of using different groups of EPPs ( 9 in total) through 10 impact measures (Table 3).Beginning with the first stage, starting/passive exporters have not yet become truly international companies. To further progress in the internationalization process, these companies require support to increase their motivation and to obtain market information and sales leads abroad. Therefore, they may benefit from all of the programs, except those intended for more advanced internationalization levels: support for investment, creation of consortia and internationalization consolidation.

Hypothesis 1. For starting/passive exporters, use of direct promotion programs, information, assistance in starting exporting and financial aid programs is positively related with the following export performance measurements:

H1.a: Improvement of economic performance, planning and market diversification.

H1.b: Achievement of intermediate results related with improvements in marketing, managers' international orientation, and obtaining information, sales leads and financing.

Regular exporters with little structure do have export experience, but they do not yet possess the skills or the resources to make the most of new opportunities for international growth in a systematic fashion.

This group requires support to develop their exports, training and information to improve export competencies, and assistance in identifying contacts and opportunities. Their level of export commitment, together with their still limited structure, causes them to require the support of programs, especially those providing sales leads, information, advising and financing. Also, this group of companies may benefit from joining export groups, which compensate for their lack of human resources.

\footnotetext{
${ }^{2}$ The distinction between stages 2 and 3 was done ex post, because the size of the export department was only known once the questionnaires had been returned.
} 
Table 3

Hypothesized relationship between program use and impact measures by export stage.

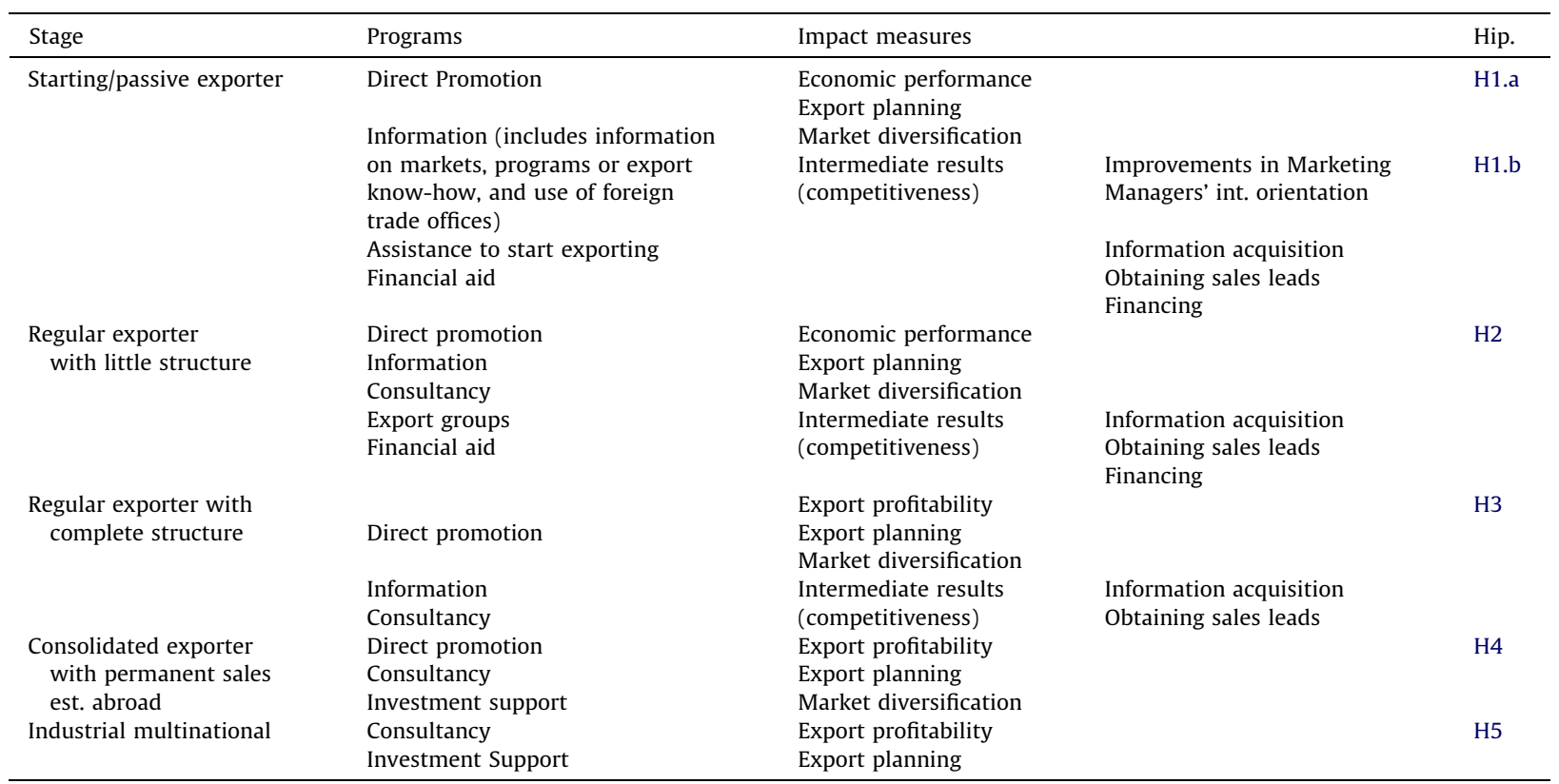

Hypothesis 2. For regular exporters with little structure, the use of information, direct promotion, consultancy, export groups and financing programs is positively related to improvements in economic performance, export planning and market diversification, as well as in intermediate results related to obtaining information, sales leads or financial assistance.

Regular exporters with a complete export structure possess their own resources and have developed internal capacities to overcome entrance barriers and enter new markets, but they require information, contacts and support to expand to new markets (Francis \& Collins-Dodd, 2004; Gençtürk \& Kotabe, 2001; Gray, 1997; Johanson \& Vahlne, 1977; Johanson \& Wiedersheim-Paul, 1975). Therefore, programs should have a positive impact regarding these aspects, and also concerning export profitability, because of the lower cost of public assistance compared with the use of other internal or external resources.

Hypothesis 3. For regular exporters with a complete structure, the use of information, direct promotion and consultancy programs, is positively related to improvements in export profitability, export planning and market diversification, as well as in intermediate results related to obtaining information or sales leads.

In addition to experience and resources, consolidated exporters with permanent sales or logistic establishments abroad have the potential to rely on their own personnel in target countries. Thus they may gather their own information and will only require assistance in entering new markets (i.e. market diversification).

Hypothesis 4. For consolidated exporters with permanent sales establishments abroad, the use of direct promotion, consultancy and investment support programs is positively associated with improvements in export profitability, export planning and market diversification.

Companies with production subsidiaries abroad (multinationals) have the strongest commitment to internationalization. We may expect EPPs to have little influence in their export performance, because they have already developed internally the necessary capabilities and resources for international success, and because part of their international sales does not come from their country of origin but from subsidiaries. ${ }^{3}$

These types of companies will probably only benefit either from consultancy programs to help them to consolidate their internationalization, or from investment support programs to improve their profitability.

Hypothesis 5. For multinationals, the use of consultancy and investment support programs is positively associated with improvements in export planning and profitability.

\footnotetext{
${ }^{3}$ Sales from subsidiaries cannot be related to the parent company using EPPs. In fact, those sales are statistically accounted for as exports from the country in which the subsidiary is located.
} 


\section{Methodology}

\subsection{Survey design}

A database was used (ACICSA), containing all of the exporting companies in the region of Catalonia (Spain), which totaled 2763 firms that included both companies with few or indirect exports and consolidated exporters.

As noted by Gençtürk and Kotabe (2001), it is recommended to limit the data collection to a single state or region because of the reported variations in the type and content of EPP between states.

Primary sector and service companies were ruled out to obtain a more homogeneous sample. Subsidiaries from multinational companies also were eliminated because the fact of belonging to a group distorts their strategies, with respect to both their marketing decisions and their export figures.

We thus created a database of 1874 manufacturing companies, which were not subsidiaries, from different sectors of the economy.

Several authors have pointed out the difficulty of obtaining reliable financial data, especially concerning exports (Archer, 1971; Barnhart, 1968; Brouthers \& Wilkinson, 2006; Katsikeas et al., 1996; Pointon, 1978). Therefore, we triangulated the financial information provided by the ACICSA database through another database called SABI, ${ }^{4}$ and also we also included one question in the questionnaire about export intensity (export sales/total sales).

\subsection{Questionnaire}

The development of the questionnaire was done in three steps: first, an extensive review was conducted of previous export promotion studies; second, in-depth interviews and pre-testing were carried out with 16 export managers coming from companies in different sectors; and third, in-depth interviews and pretesting were carried out with an ICEX ${ }^{5}$ representative.

This first version of the questionnaire was tested with 12 companies, as well as with new ICEX and ACCIÓ10 representatives.

These participants' comments resulted in an improvement and simplification of some of the questions, and confirmed the appropriateness of using export managers as key informants regarding the issues addressed in this study.

Each company was called first to try to obtain the export manager's name and his authorization to send the questionnaire. We thus obtained correct contact data for 1210 companies.

The questionnaire was then sent, in 2005, by mail to each export director along with a self-addressed, stamped envelope and an endorsement letter from the university.

After this first mailing, 215 usable answers were received (a 17.77\% response rate). Following Dillman (2002), a follow-up letter was sent to 400 of the previously contacted companies. After this new letter, 57 new answers were received, which increased the number of usable responses to 272 (22.48\% response rate). This sample size is slightly higher than that reported by most researchers in this area. To evaluate non-response bias, early and late respondents were compared (trend analysis), resulting in no significant differences.

We conducted a complete inventory of all the EPPs offered to companies in the region and found 15 types of programs. Table 5 includes the full list of programs, together with the first necessary impact measure, which consists of the degree of awareness and use of the different programs. We also calculated the relationship between awareness and use, which is called Use Effectiveness Index (Naidu \& Rao, 1993).

EPPs awareness and use provide an interesting evaluation of the effectiveness of the programs' communication, but not of the programs' contribution to export performance.

It is thus necessary to measure the programs' effects not only in final economic performance but also in intermediate results. These are the foundations that will enable the firm to compete internationally and achieve export success, and therefore their improvement is the main EPPs objective (Spence, 2003; Francis \& Collins-Dodd, 2004).

In this study a comprehensive set of multidimensional indicators was included, considering both perceptions and objective/financial results, which was classified in three categories:

- Economic results: volume, growth, intensity and profitability of international sales.

- Export diversification: number of export areas and percentage of exports outside the European Union.

- Competitiveness. Degree of achievement of different intermediate results, regarding the following items:

- information on business practices;

- managers motivation;

- market information;

- marketing competencies: after-sales service, product adaptation, packaging, promotion activities, distribution network and pricing internationally;

\footnotetext{
${ }^{4} \mathrm{SABI}$ includes complete information and financial data coming from official sources such as stock exchange, press and company registers, and therefore it has a high degree of reliability.

${ }^{5}$ ICEX refers to the Instituto Español de Comercio Exterior, which is the main Spanish export promotion organization.

${ }^{6}$ ACCIÓ10 is the main export promotion organization for companies from Catalonia.
} 
- financing;

- opening branch offices or subsidiaries;

- reaching international alliances or cooperation agreements; and

- internationalization planning.

These items make up a set of complementary indicators of a company's competitiveness in the international market. They were selected based on previous research mainly by Hibbert (1990), Crick and Czinkota (1995), who found that product adaptation was the most important success factor, and Seringhaus (1986), who determined that the creation of a sales network was paramount.

Economic results regarding export volume, growth and intensity were found in the databases mentioned before and also checked through the questionnaire. The respondents were asked to compare Export profitability with national sales, on a ten-point scale ranging from "much less profitable" to "much more profitable".

Regarding competitiveness indicators, firms were asked the degree of perceived accomplishment of each of the 15 intermediate results, measured on a ten-point scale ranging from "not achieved" to "completely achieved".

In order to measure the level of use of each EPP, managers were asked how frequently they used them, with 5 possible answers ranging from "hardly ever" to "constantly". Some EPPs, as the program to support companies starting to export, can only be used once, so the question was simply whether they had or had not used it.

\section{Data analysis and results}

The 272 companies in the sample had on average 193 employees, total sales of $€ 21.3$ million, $€ 7.37$ million in exports (an export intensity of 34.5\%), and an export department with 4.3 members. These exports have grown €3.32 million in the last five years, and mostly were directed to the European Union (85\% of companies directed more than $60 \%$ of their exports to other European countries).

Table 4

Sample features by level of international involvement.

\begin{tabular}{|c|c|c|c|c|c|c|}
\hline \multirow[t]{2}{*}{ Features } & \multicolumn{5}{|c|}{ Internationalization stage } & \multirow[t]{2}{*}{ Mean } \\
\hline & $1(n=38)$ & $2(n=89)$ & $3(n=74)$ & $4(n=47)$ & $5(n=24)$ & \\
\hline \multicolumn{7}{|l|}{ Basic information } \\
\hline Sales volume (in $\mathrm{M} €$ ) & 3.06 & 8.5 & 15.8 & 28.2 & 101.3 & $21.33^{* * *}$ \\
\hline Number of employees & 28 & 56 & 82 & 170 & 1347 & $193^{* * *}$ \\
\hline Years in operation & 31.8 & 36.2 & 44.8 & 42 & 51 & $40.2^{* *}$ \\
\hline Years exporting & 8.7 & 15.7 & 22.5 & 20.5 & 25.6 & $18.1^{* * *}$ \\
\hline Members of export department & 2.1 & 1.7 & 5.1 & 6.4 & 11.3 & $4.3^{* * *}$ \\
\hline \multicolumn{7}{|l|}{ Internationalization performance } \\
\hline Export sales $(2005$, in $M €)$ & 0.22 & 1.70 & 5.57 & 9.12 & 41.75 & $7.37^{* * *}$ \\
\hline Export intensity (\% exp/total sales) & $7.3 \%$ & $26.9 \%$ & $35.2 \%$ & $40.0 \%$ & $41.2 \%$ & $34.5 \%^{* * *}$ \\
\hline Export growth $(\mathrm{M} €, n-3)^{\mathrm{a}}$ & 0.04 & 0.29 & 1.48 & 3.14 & 5.66 & $1.54^{* * * *}$ \\
\hline Export growth $(\mathrm{M} €, n-5)$ & 0.14 & 0.75 & 2.57 & 4.80 & 17.30 & $3.32^{* * *}$ \\
\hline Export profitability $^{\mathrm{b}}$ & 4.8 & 5.2 & 5.9 & 5.3 & 6.1 & $5.4^{* *}$ \\
\hline \multicolumn{7}{|l|}{ Export diversification } \\
\hline Number of export areas & 1.68 & 3.01 & 3.39 & 4.43 & 5.21 & $3.56^{* * *}$ \\
\hline \multicolumn{7}{|l|}{ Percentage of exports outside EU } \\
\hline From 0 to $20 \%$ & $89 \%$ & $71 \%$ & $54 \%$ & $45 \%$ & $42 \%$ & $62 \%$ \\
\hline 21 to $40 \%$ & $3 \%$ & $22 \%$ & $24 \%$ & $32 \%$ & $33 \%$ & $23 \%$ \\
\hline 41 to $70 \%$ & $3 \%$ & $4 \%$ & $16 \%$ & $17 \%$ & $25 \%$ & $11 \%$ \\
\hline + Than $70 \%$ & $5 \%$ & $2 \%$ & $7 \%$ & $6 \%$ & $0 \%$ & $4 \%$ \\
\hline Planning of internationalization & 4.3 & 5 & 6.6 & 6.4 & 7.3 & $5.8^{* * *}$ \\
\hline \multicolumn{7}{|l|}{ Number of subsidiaries } \\
\hline Sales & 0.4 & 0.3 & 0.2 & 2.3 & 5.8 & $1.1^{* * *}$ \\
\hline Production & 0 & 0.1 & 0 & 0.1 & 3.3 & $0.3^{* * *}$ \\
\hline \multicolumn{7}{|l|}{ Managers' global orientation } \\
\hline Number of international trips per year & 5.7 & 8.4 & 13 & 16.2 & 14.4 & $11^{* * *}$ \\
\hline Stays abroad (months) & 6.0 & 2.9 & 9.3 & 15.8 & 24.2 & 8.3 \\
\hline Wish to repeat stays abroad ${ }^{\mathrm{c}}$ & $37 \%$ & $51 \%$ & $55 \%$ & $60 \%$ & $46 \%$ & $51 \%$ \\
\hline Knowledge of languages (number) & 2.1 & 2.4 & 2.6 & 2.8 & 1.4 & $2.5^{* * *}$ \\
\hline
\end{tabular}

Notes:

a Export growth compared to the results 3 and 5 years earlier.

b Perception of the profitability of exports compared to local sales (Likert scale from 0 to 10).

c Percentage of managers who have expressed their wish to live again abroad.

ANOVA tests of significant differences between groups of firms.

** Indicates significant differences between groups, $p<0.05$.

Indicates significant differences between groups, $p<0.01$. 
As shown in Table 4, companies in different internationalization stages showed clearly differentiated features regarding Basic Information, Export Performance, and Managers' Global Orientation, which validates the chosen classification criteria summarized in Table 2.

There is a positive relationship between size (both as measured by Annual Sales and by Number of Employees), and Export Involvement. This is also an interesting finding, because previous researchers are not unanimous regarding the relationship between company size and export performance. While some conclude that there is a positive relationship (Czinkota \& Johnston, 1983; Spence, 2003), for others this positive link cannot be proven (Diamantopoulos \& Inglis, 1988; Katsikeas et al., 1996).

For the first time in this line of research exporters with production subsidiaries (multinational companies) were considered as a separate group. Notably, these companies (stage 5) show clearly distinct features for all of the description variables, which justifies the addition of this internationalization stage.

Years in Operation has a logical positive relationship with Years exporting and with Members of the Export Department. Thus, in spite of the new tendencies of born global companies, firms with more years in operation are the ones with more personnel working in international business, and with better export performance.

Regarding managers' global orientation, those from companies in stage 4 have the highest number of international trips and knowledge of languages (with an average of 3languages which may be considered remarkably high). Managers from companies in stage 5 stand out for the number of months staying abroad, although with a low willingness to repeat these stays. These are logical results, since managing foreign subsidiaries requires executives who travel frequently in different countries and who are able to deal with personnel with different languages and cultures. After these managers have spent some time working in a foreign division, they wish to come back and stay in their home country.

In this regard, previous research (Gray, 1997), considered the possibility that starting exporters would have highly internationally experienced managers, and therefore they maintained that the programs should be segmented according to managers rather than firms. This study's results, however, show that it is companies in more advanced stages that also have managers with more international experience.

Finally, it is noteworthy that findings show that as companies progress through the internationalization process, they more carefully plan their internationalization, they obtain better economical results (export sales, intensity and export growth), and they also achieve a higher market diversification.

\subsection{Awareness and use of EPPS}

Awareness and use are both higher for "classic" programs: sponsored trade shows and trade missions (Table 5). Among exporters, 73\% know the support for trade exhibitions, and 76\% trade missions, with a use of 59 and $63 \%$, respectively. The Use Effectiveness Index is also higher for these programs ( $81 \%$ and 83\%, respectively). That is to say, 8 out of 10 exporters who know these EPPs use them, which shows that exporters both understand and trust the effects of these programs.

Both awareness and use are considerably lower for information programs. It is especially remarkable that only $43 \%$ of exporters know the services offered by the OFECOMES (network of ICEX promotional offices abroad), considering their low cost and usefulness in getting information about new markets. As a result of their higher awareness, companies in stages 4 and 5 mostly use this service (over half). These are not however the kind of exporters who in theory need it more, because they already have their own personnel and establishments abroad to supply them with the information they need.

Instead, the level of awareness for CPNs (ACCIO10 promotional offices abroad) (63\%)and their use (42\%) can be considered high, especially if we take into consideration that their cost is higher and actually close to that of a private consultancy.

Starting exporters show a remarkably low level of awareness of "Programs for assistance to start exporting", considering that these exporters are the target of this type of program. Given that most of the exporters in stage 1 who know this program use it $(80 \%)$, it is clear that more communication is required. Companies in more advanced stages logically do not use these programs, because they are not addressed to them.

Also, it is reasonable that starting exporters have a low level of use of the "consultancy program for consolidated exporters", because they are not targeted for this kind of program. Instead, awareness of these programs by companies in stages 3-5 is unsatisfactory (less than half), and the number of users is insignificant (less than $7 \%$ ). This is probably due to a widespread perception by companies that consultancy in strategy is not really very useful in practice.

In the same way, it is logical that exporters in the first three stages have a low awareness of the "program to support the creation of production subsidiaries". However, it is also quite low for exporters who invest abroad (stages 4 and 5 , with $22 \%$ and $46 \%$ respectively). But here again, we find a high Use Effectiveness Index by the target group (multinational companies, over $80 \%$ of those who know it use it).

Programs helping the creation of export groups and consortium have quite a low level of awareness and a still lower use (less than 6\%). This lack of awareness and use can be considered logical, because many companies do not have a product which may be exported together with other companies. Also, the process to create this kind of alliance is complex and often it is difficult to find the appropriate partners.

Besides, global results show that the number of programs known and used increase with the export involvement of firms. Starting/passive exporters know and use the least number of programs.

At the same time, the Use Effectiveness Index is similar for the 5 stages. This finding shows again the need to increase communication towards companies that are starting to export. They use about half the amount of programs of exporters in 
Table 5

Number of firms which know and use each program by level of export involvement.

\begin{tabular}{|c|c|c|c|c|c|c|c|}
\hline \multirow[t]{2}{*}{ Program awareness and use } & \multicolumn{5}{|c|}{ Internationalization stage } & \multirow[t]{2}{*}{ Total } & \multirow{2}{*}{$\begin{array}{l}\text { Use effectiveness } \\
\text { index }(\%)\end{array}$} \\
\hline & $1(n=38)$ & $2(n=89)$ & $3(n=74)$ & $4(n=47)$ & $5(n=24)$ & & \\
\hline \multicolumn{8}{|l|}{ Sales promotion } \\
\hline \multirow[t]{2}{*}{ - Sponsored Foreign trade shows } & 20 & 66 & 55 & 40 & 17 & 198 & 81 \\
\hline & 14 & 53 & 46 & 32 & 15 & $160^{* *}$ & \\
\hline \multirow[t]{2}{*}{ - Trade missions } & 23 & 69 & 56 & 41 & 17 & 206 & 83 \\
\hline & 16 & 55 & 51 & 34 & 15 & $171^{*}$ & \\
\hline \multirow[t]{2}{*}{ - Support for brand promotion } & 8 & 28 & 23 & 23 & 11 & $93^{* *}$ & 31 \\
\hline & 0 & 9 & 8 & 7 & 5 & $29^{* *}$ & \\
\hline \multirow[t]{2}{*}{ Information on foreign markets } & 19 & 47 & 46 & 34 & 12 & 158 & 68 \\
\hline & 11 & 31 & 34 & 24 & 8 & 108 & \\
\hline \multirow[t]{2}{*}{ Seminars, Newsletters... about the programs } & 17 & 47 & 44 & 27 & 13 & 148 & 63 \\
\hline & 9 & 31 & 30 & 16 & 7 & 93 & \\
\hline \multirow[t]{2}{*}{ Internationalization training initiatives } & 19 & 56 & 38 & 30 & 12 & 155 & 63 \\
\hline & 13 & 32 & 24 & 20 & 8 & 97 & \\
\hline \multicolumn{8}{|l|}{ Foreign trade offices } \\
\hline \multirow{2}{*}{$\begin{array}{l}\text { - OFECOMEs: network of ICEX promotional } \\
\text { offices abroad. }\end{array}$} & 10 & 37 & 31 & 27 & 12 & 117 & 72 \\
\hline & 8 & 32 & 22 & 19 & 9 & 90 & \\
\hline \multirow{2}{*}{$\begin{array}{l}\text { - CPNs: network of ACCIO10 promotional } \\
\text { offices abroad }\end{array}$} & 17 & 51 & 50 & 36 & 18 & $172^{* *}$ & 66 \\
\hline & 8 & 29 & 35 & 26 & 15 & $113^{* * *}$ & \\
\hline \multirow[t]{2}{*}{ Direct financial/economic support } & 14 & 39 & 27 & 25 & 12 & 117 & 70 \\
\hline & 10 & 24 & 19 & 19 & 10 & 82 & \\
\hline \multirow{2}{*}{$\begin{array}{l}\text { Program to support companies } \\
\text { starting to export }\end{array}$} & 14 & 49 & 28 & 24 & 11 & 126 & 35 \\
\hline & 12 & 19 & 7 & 4 & 2 & $44^{* *}$ & \\
\hline \multirow{2}{*}{$\begin{array}{l}\text { Consultancy Program for consolidated } \\
\text { exporters }\end{array}$} & 4 & 23 & 18 & 21 & 10 & $\mathbf{7 6}^{* * *}$ & 14 \\
\hline & 1 & 3 & 4 & 3 & 0 & 11 & \\
\hline \multirow[t]{2}{*}{ Export groups or consortium } & 6 & 29 & 29 & 21 & 9 & $94^{*}$ & 17 \\
\hline & 0 & 5 & 7 & 2 & 2 & $16^{*}$ & \\
\hline \multirow[t]{2}{*}{ Personalized advice } & 3 & 13 & 14 & 17 & 4 & $51^{* * *}$ & 10 \\
\hline & 0 & 1 & 2 & 2 & 0 & $5^{* * *}$ & \\
\hline \multicolumn{8}{|l|}{ Investment support } \\
\hline \multirow{2}{*}{$\begin{array}{l}\text { - Support to create production s } \\
\text { ubsidiaries }\end{array}$} & 5 & 20 & 14 & 13 & 11 & $63^{*}$ & 25 \\
\hline & 2 & 2 & 2 & 1 & 9 & $16^{* * *}$ & \\
\hline \multirow[t]{2}{*}{ - Support to create sales subsidiaries } & 4 & 19 & 14 & 20 & 14 & $71^{* * *}$ & 35 \\
\hline & 2 & 1 & 0 & 11 & 11 & $25^{* * *}$ & \\
\hline \multirow[t]{2}{*}{ Total } & 169 & 544 & 459 & 375 & 172 & 1719 & 59 \\
\hline & 94 & 308 & 284 & 216 & 114 & 1016 & \\
\hline \multirow[t]{2}{*}{ Mean number of programs known and used } & 4.4 & 6.1 & 6.2 & 8.0 & 7.2 & 6.3 & \\
\hline & 2.5 & 3.5 & 3.8 & 4.6 & 4.8 & 3.7 & \\
\hline Use effectiveness index & $56 \%$ & $57 \%$ & $62 \%$ & $58 \%$ & $66 \%$ & & \\
\hline
\end{tabular}

Chi-square tests/ANOVA of significant differences between groups of companies.

* Indicates significant differences between groups, $p<0.10$.

** Indicates significant differences between groups, $p<0.05$.

I*** Indicates significant differences between groups, $p<0.01$.

stage 5,although in theory they would need them more. In any case, these use indexes could be increased, through more effective communication and by improving the perception of the programs by their potential users.

\subsection{Impact of each type of program on economic results, market diversification and competitive advantage}

The relationship between the use of each program and the different impact measures was examined through bivariate correlations.

Globally, we observe a positive relationship between program use and export diversification, as well as with several intermediate results. However, we did not find significant correlations with economic performance.

The impact varies depending on the internationalization stage of the firm, as well as on the type of program.

\subsubsection{Analysis by export involvement}

5.2.1.1. Stage 1: starting/passive exporters. From the group of correlation tables we see that, as expected (H1), starting exporters experience positive correlations with a high number of impact measures. In fact, this is the group, together with exporters in stage 2 , that has the highest number of positive relations. 
Table 6

Correlations between use of direct promotion programs and the different measures of impact.

\begin{tabular}{|c|c|c|c|c|c|c|}
\hline \multirow[t]{2}{*}{ Measures of impact } & \multicolumn{5}{|c|}{ Internationalization stage } & \multirow[t]{2}{*}{ Total } \\
\hline & $1(n=38)$ & $2(n=89)$ & $3(n=74)$ & $4(n=47)$ & $5(n=24)$ & \\
\hline \multicolumn{7}{|l|}{ Economic results ${ }^{*}$} \\
\hline - Export sales & -0.094 & $-0.243^{*}$ & 0.017 & -0.109 & -0.264 & -0.062 \\
\hline - Export intensity & 0.188 & 0.078 & 0.074 & -0.001 & 0.129 & -0.008 \\
\hline - Export growth $(\mathrm{M} €, n-3)$ & -0.184 & 0.016 & -0.054 & -0.283 & -0.262 & -0.073 \\
\hline - Export growth $(\mathrm{M} €, n-5)$ & 0.080 & -0.088 & 0.105 & -0.282 & -0.282 & -0.057 \\
\hline - Export profitability & 0.131 & 0.081 & -0.002 & -0.071 & $0.443^{*}$ & $0.142^{*}$ \\
\hline \multicolumn{7}{|l|}{ Export diversification* } \\
\hline - Number of export areas & $0.399^{*}$ & $0.378^{* *}$ & $0.338^{* *}$ & 0.253 & $0.449^{*}$ & $0.344^{* *}$ \\
\hline - Percentage of exports outside EU & 0.017 & 0.082 & 0.038 & 0.241 & $0.430^{*}$ & $0.191^{* *}$ \\
\hline \multicolumn{7}{|l|}{ Intermediate results ${ }^{*}$} \\
\hline - Market information gathering & -0.011 & 0.075 & 0.196 & 0.182 & 0.168 & $0.203^{* *}$ \\
\hline - Financing & -0.008 & 0.137 & 0.059 & -0.006 & -0.011 & 0.096 \\
\hline - Obtaining export contacts & 0.228 & $0.278^{*}$ & 0.233 & -0.065 & -0.130 & 0.139 \\
\hline - Improvement of after-sales service & 0.119 & 0.196 & 0.104 & -0.164 & -0.272 & 0.033 \\
\hline - Product adaptation & 0.094 & $0.285^{*}$ & -0.090 & -0.180 & -0.525 & 0.016 \\
\hline - Packaging & 0.261 & 0.044 & -0.090 & -0.287 & 0.403 & 0.065 \\
\hline - Obtaining financial information & 0.096 & 0.033 & 0.178 & $-0.343^{*}$ & -0.245 & 0.067 \\
\hline - Promotion activities & $0.451^{*}$ & 0.168 & $0.433^{* *}$ & 0.000 & -0.100 & $0.319^{* * *}$ \\
\hline - Pricing internationally & 0.355 & 0.049 & 0.210 & -0.037 & -0.274 & $0.170^{*}$ \\
\hline - Information on business practices & 0.110 & $0.263^{*}$ & 0.192 & 0.022 & -0.010 & $0.189^{*}$ \\
\hline - Managers' motivation & 0.208 & 0.113 & 0.086 & -0.047 & -0.162 & 0.094 \\
\hline - Creation of an agents/distributor network & $0.652^{* *}$ & $0.447^{* *}$ & $0.289^{*}$ & -0.017 & -0.199 & $0.297^{* *}$ \\
\hline - Alliances/cooperation agreements & $0.436^{*}$ & $0.350^{* *}$ & -0.028 & -0.011 & 0.158 & 0.158 \\
\hline - Internationalization planning & $0.489^{* *}$ & $0.219^{*}$ & 0.137 & 0.182 & -0.167 & $0.186^{* *}$ \\
\hline - Opening branch offices or subsidiaries & - & - & -0.011 & -0.006 & -0.077 & -0.012 \\
\hline
\end{tabular}

Indicates significant differences between groups, $p<0.10$

** Indicates significant differences between groups, $p<0.05$.

There are no significant correlations with any economic results. Remarkably, the measures of performance achieved by companies in stage 1 were consistent with the objectives of each type of program.

The results indicate that for starting exporters, a higher use of trade missions and sponsored foreign trade shows is positively related with a wider range of export areas, improvements in product marketing, achievement of cooperation agreements, and better internationalization planning (Table 6).

The use of information programs (Table 7), is, as expected, positively related to obtaining information about the market, knowledge of business practices and the creation of a sales network.

As for programs supporting companies starting to export, stage 1 companies that use these programs have better intermediate results (Table 8), except for diversification and economic performance. This is the only stage with such clear results.

5.2.1.2. Stage 2: regular exporters with little structure. This group requires support to develop their exports further. As expected, the use of direct export promotion programs and information programs, is positively correlated with a high number of impact measures (H2).

As with starting exporters, we do not find a positive relationship with economic results, but we do find such a relationship with the intermediate results that are in line with the objective of each program.

5.2.1.3. Stage 3: regular exporters with complete structure. For regular exporters with a complete export structure, as expected, the use of direct promotion programs, information or investment support programs is correlated with a higher number of export markets (H3).

Furthermore, the use of direct promotion or information programs is positively associated with the creation of a sales network in the foreign markets.

5.2.1.4. Stage 4: regular exporters with sales or logistics subsidiaries. Exporters in stage 4 are very experienced, consolidated exporters; at this stage, the use of programs has less impact than for any other group. Concurrently, we do not see, as previously stated (H4), a significant relationship with better planning or market diversification.

This is most likely because these companies have already internally developed the capacities and resources needed to plan and carry out their activities in different geographical areas. Thus, they achieve export diversification regardless of program use.

5.2.1.5. Stage 5: multinational companies. Companies with production subsidiaries have the highest commitment of resources in foreign markets. They have already internally developed the necessary resources for internationalization; thus we expected programs to have little effect (H5). 
Table 7

Correlations between use of information programs and the different measures of impact.

\begin{tabular}{|c|c|c|c|c|c|c|}
\hline \multirow[t]{2}{*}{ Measures of impact } & \multicolumn{5}{|c|}{ Internationalization stage } & \multirow[t]{2}{*}{ Total } \\
\hline & $1(n=38)$ & $2(n=89)$ & $3(n=74)$ & $4(n=47)$ & $5(n=24)$ & \\
\hline \multicolumn{7}{|l|}{ Economic results $^{*}$} \\
\hline - Export sales & -0.078 & -0.108 & 0.222 & -0.046 & -0.121 & -0.011 \\
\hline - Export intensity & 0.131 & 0.010 & 0.110 & -0.169 & 0.051 & $-0.154^{*}$ \\
\hline - Export growth $(\mathrm{M} €, n-3)$ & 0.032 & 0.021 & 0.134 & -0.152 & -0.186 & -0.002 \\
\hline - Export growth $(\mathrm{M} €, n-5)$ & 0.240 & -0.011 & 0.148 & -0.207 & -0.195 & -0.005 \\
\hline - Export profitability & 0.072 & 0.158 & 0.015 & 0.047 & 0.038 & 0.085 \\
\hline \multicolumn{7}{|l|}{ Export diversification ${ }^{*}$} \\
\hline - Number of export areas & 0.197 & 0.188 & 0.182 & 0.193 & 0.300 & $0.250^{* *}$ \\
\hline - Percentage of exports outside EU & -0.090 & 0.158 & 0.122 & 0.107 & 0.214 & $0.157^{* *}$ \\
\hline \multicolumn{7}{|l|}{ Intermediate results ${ }^{*}$} \\
\hline - Market information gathering & $0.464^{* *}$ & $0.377^{* *}$ & 0.217 & 0.028 & 0.066 & $0.300^{* *}$ \\
\hline - Financing & $0.478^{* *}$ & 0.198 & 0.017 & -0.143 & 0.080 & 0.100 \\
\hline - Obtaining export contacts & 0.361 & $0.367^{* *}$ & 0.197 & 0.282 & 0.180 & $0.378^{* *}$ \\
\hline - Improvement of after-sales service & 0.267 & 0.220 & 0.135 & -0.044 & 0.413 & $0.265^{* *}$ \\
\hline - Product adaptation & 0.259 & 0.209 & -0.050 & -0.080 & -0.431 & $0.214^{* *}$ \\
\hline - Packaging & 0.252 & $0.302^{*}$ & -0.036 & -0.281 & 0.528 & 0.101 \\
\hline - Obtaining financial information & 0.205 & 0.090 & 0.118 & 0.058 & 0.299 & $0.174^{*}$ \\
\hline - Promotion activities & 0.304 & $0.233^{*}$ & $0.273^{*}$ & 0.166 & 0.269 & $0.332^{* *}$ \\
\hline - Pricing internationally & 0.334 & 0.239 & 0.190 & 0.141 & 0.193 & $0.222^{* *}$ \\
\hline - Information on business practices & $0.428^{*}$ & $0.287^{*}$ & 0.222 & 0.169 & 0.456 & $0.326^{* *}$ \\
\hline - Managers' motivation & 0.172 & 0.138 & 0.058 & -0.068 & $0.505^{*}$ & $0.206^{* *}$ \\
\hline - Creation of an agents/distributor network & $0.510^{* *}$ & $0.323^{* *}$ & $0.280^{*}$ & 0.102 & 0.197 & $0.381^{* *}$ \\
\hline - Alliances/cooperation agreements & 0.269 & $0.347^{* *}$ & 0.026 & -0.103 & 0.391 & 0.132 \\
\hline - Internationalization planning & $0.359^{*}$ & 0.138 & 0.146 & 0.046 & 0.088 & 0.030 \\
\hline - Opening branch offices or subsidiaries & - & - & 0.194 & -0.241 & -0.065 & 0.046 \\
\hline
\end{tabular}

* Indicates significant correlation, $p<0.05$.

** Indicates significant correlation, $p<0.01$.

Table 8

Mean outcomes of companies using and not using the program to support companies starting to export.

\begin{tabular}{|c|c|c|c|c|c|c|c|c|c|c|}
\hline \multirow[t]{3}{*}{ Measures of impact } & \multicolumn{10}{|c|}{ Internationalization stage } \\
\hline & \multicolumn{2}{|c|}{$1 n=38$} & \multicolumn{2}{|c|}{$2 n=89$} & \multicolumn{2}{|c|}{$3 n=74$} & \multicolumn{2}{|c|}{$4 n=47$} & \multicolumn{2}{|c|}{$5 n=24$} \\
\hline & User & No U. & User & No U. & User & No U. & User & No U. & User & No U. \\
\hline \multicolumn{11}{|l|}{ Economic results $^{*}$} \\
\hline - Export sales & 0.16 & 0.25 & 1.04 & 1.89 & 2.16 & 5.93 & 4.27 & 9.57 & 9.46 & 44.7 \\
\hline - Export intensity & 10.1 & 7.1 & 28.4 & 26.5 & 29.6 & 42.9 & 34.5 & 40.5 & 28.9 & 45.5 \\
\hline - Export growth $(\mathrm{M} €, n-3)$ & 0.02 & 0.05 & 0.42 & 0.25 & 0.94 & 1.54 & 1.50 & 3.29 & 1.20 & 6.07 \\
\hline - Export growth $(\mathrm{M} €, n-5)$ & 0.03 & 0.09 & 0.69 & 0.76 & 2.55 & 2.58 & 2.79 & 4.99 & 1.63 & 18.72 \\
\hline - Export Profitability & 4.5 & 4.9 & 5.16 & 5.21 & 5.57 & 5.91 & 5.50 & 5.28 & 8.00 & 5.95 \\
\hline \multicolumn{11}{|l|}{ Export diversification ${ }^{*}$} \\
\hline - Number of export areas & 1.8 & 1.6 & 2.7 & 3.1 & 3.1 & 4.18 & 3.5 & 4.5 & 5.0 & 5.2 \\
\hline - Percentage of exports outside EU & 2.2 & 2.6 & 2.8 & 2.7 & 3.1 & 3.6 & 3.0 & 3.8 & 4.0 & 3.6 \\
\hline \multicolumn{11}{|l|}{ Intermediate results $^{*}$} \\
\hline - Market information gathering & 6.7 & $4.2^{* * *}$ & 5.89 & 6.16 & 5.57 & 6.79 & 7.50 & 6.90 & 8.50 & 8.18 \\
\hline - Financing & 5.5 & $3.5^{*}$ & 5.22 & 4.10 & 4.50 & 5.40 & 5.00 & 4.95 & 3.50 & 7.27 \\
\hline - Obtaining export contacts & 7.1 & $3.8^{* * *}$ & 6.11 & 5.96 & 5.17 & 6.70 & 6.50 & 6.45 & 6.50 & 7.63 \\
\hline - Improve after-sales service & 6.1 & 4.3 & 4.69 & 5.23 & 6.60 & 6.27 & 6.67 & 6.35 & 5.00 & 6.89 \\
\hline - Product adaptation & 5.9 & 4.5 & 6.31 & 5.88 & 6.17 & 6.75 & 6.75 & 7.15 & 10.00 & 7.60 \\
\hline - Packaging & 5.8 & 5.1 & 5.64 & 5.20 & 5.57 & 6.31 & 6.33 & 6.83 & & 7.00 \\
\hline - Obtaining financial information & 5.5 & 4.3 & 5.24 & 5.88 & 5.80 & 6.44 & 6.50 & 6.58 & 5.00 & 6.25 \\
\hline - Promotion activities & 6.9 & $4.1^{* *}$ & 6.78 & 6.49 & 6.14 & 6.97 & 7.75 & 6.90 & 7.50 & 7.38 \\
\hline - Pricing internationally & 6.3 & $4.4^{* *}$ & 5.28 & 6.02 & 5.80 & 5.81 & 8.00 & 6.63 & 10.00 & 6.75 \\
\hline - Information on business practices & 7.2 & $4.8^{* * *}$ & 7.00 & 6.46 & 5.57 & 6.97 & 8.50 & 7.64 & 10.00 & 7.29 \\
\hline - Managers' motivation & 7.4 & $5.4^{* *}$ & 7.11 & 6.76 & 7.14 & 7.66 & 8.50 & 7.43 & 5.00 & 7.43 \\
\hline - Creation agents/distributor network & 7.1 & $3.5^{* * *}$ & 5.72 & 5.31 & 5.43 & 6.29 & 8.50 & 7.18 & 5.00 & 7.31 \\
\hline - Alliances/cooperation agreements & 6.0 & $3.1^{* * *}$ & 4.53 & 4.32 & 3.60 & 4.78 & 6.00 & 5.46 & 1.00 & 6.31 \\
\hline - Internationalization planning & 6.7 & $3.6^{* * *}$ & 5.74 & 4.86 & 6.57 & 6.57 & 6.50 & 6.37 & 7.50 & 7.32 \\
\hline - Opening offices or subsidiaries & - & - & - & - & 0.2 & 0.0 & 2.00 & 2.55 & 7.00 & 9.27 \\
\hline
\end{tabular}

\footnotetext{
* Indicates significant differences between groups, $p<0.10$.

** Indicates significant differences between groups, $p<0.05$.

Indicates significant differences between groups, $p<0.01$.
} 
However, the results show that multinational companies seem to benefit from programs as to market diversification and export profitability. Most likely, multinational companies that use the programs are the ones that also are more interested in entering new countries. Thus they are able to achieve a higher market diversification, and require less investment to continue do so.

\subsection{Analysis by type of program}

Use of direct promotion programs (trade missions and sponsored trade shows) is positively related to market diversification independently of the internationalization stage of the firm.

Both of these and information programs enable exporters in stages 1 and 2 to make progress in the aspects they support: the improvement of promotion actions abroad and the creation of a sales network.

Use of programs to support companies starting to export, consistent with their objective, has just a positive effect in exporters in stage 1 , and only regarding intermediate results (Table 8 ).

Regarding consultancy programs, we tested and did not find any significant relationship between their use and export outcomes for any stage, although it is difficult to draw conclusions given the very limited number of companies that use these programs (only about $4 \%$ )

Finally, as to investment support programs, the only significant impact obtained relates to a higher number of subsidiaries for companies in stage 4 .

\section{Discussion}

Revised literature has emphasized the need to proceed through a thorough evaluation of EPPs, using a rigorous approach that takes into account the different methodological recommendations. This is the first study that takes them all into consideration and that evaluates EPPs both collectively and individually, using a wide range of intermediate and final impact measures, segmented according to export involvement.

In the survey design, innovative export involvement segmentation criteria were used and the sample features proved that groups were heterogeneous. Furthermore, the results support the idea of progressive acquisition and integration of knowledge and skills as companies move forward through the internationalization process, in alignment with Uppsala theory (Johanson \& Vahlne, 1977).

The global EPP impact analysis showed a relationship between use of programs and some diversification and intermediate outcomes, but not with economic measures.

These results are consistent with the objectives of EPPs: they are expected to help companies become more competitive internationally, but the final achievement of exports depends on other variables beyond program control.

These findings also reinforce previous research. Gençtürk and Kotabe (2001) concluded that EPPs bring about results primarily in export diversification and profitability, rather than in export sales. Francis and Collins-Dodd (2004) also found a positive relationship between program use, and impact measures related to company objectives, strategies and competencies, but not with economic measures. Fayos (2003) concluded that companies receive only indirect benefits from promotion (improvement in managers skills and sales leads), but not direct benefits (economic results). Finally, Seringhaus (1984) did not find a relationship between the use of a program (trade missions) and two performance outcomes (export intensity and number of orders), but it did with other indirect indicators, such as the number of export contacts.

Regarding analysis by export involvement, as expected, exporters in the initial exporting stages are the ones that experience positive correlations with a higher number of impact measures. These companies need more support in order to develop their exports, training and information in order to become more competitive, and help in order to identify contacts and opportunities. These effects also coincide with those from previous studies, which found that companies have different needs depending on their internationalization stage (Czinkota \& Kotabe, 1992; Naidu \& Rao, 1993); and more specifically, that firms in more advanced internationalization stages are the onesthat perceive or experience less usefulness in EPPs (Francis \& Collins-Dodd, 2004; Czinkota, 1982; Seringhaus \& Rosson, 1990).

For the first time, the individual impact of each EPP was measured. The analysis by type of program has shown that use of direct promotion programs, results in a higher number of export markets, regardless of the internationalization stage. Thus, using these programs (basically trade missions and sponsored trade shows) enables the company to enter into markets that, because of the lack of information and local contacts, would not have access without institutional assistance. Furthermore, both direct promotion and information programs fulfill their objective by enabling exporters in stages 1 and 2 to improve their promotion activities and the creation of an international sales network. These results are consistent with previous studies on the impact of trade missions and sponsored trade shows from Seringhaus and Rosson (1998) and Brouthers and Wilkinson (2006), who also found positive effects for these specific programs.

Additionally, the program to support companies to start exporting, accomplishes its purpose by helping exporters in stage 1 achieve a wide range of intermediate results. Specifically, they may become more competitive by obtaining more information on international markets, obtaining more business contacts, and by developing their marketing competencies. 


\subsection{Implications for management and EPOs}

Results show that companies in the initial export stages can become more competitive by using most available EPPs. Therefore, managers in companies from this segment should be especially active in gathering information about the programs and increasing their participation therein.

The highest impact was thus found for firms beginning and developing their internationalization process, but paradoxically consolidated exporters were the ones who knew and therefore used more programs. At the same time, starting exporters have a high Use Effectiveness Index for the programs intended for them, because most of those who know these programs use them. Consequently, EPOs should make an effort to communicate, specifically targeting starting exporters, and should prioritize their participation of starting exporters over that of more experienced exporters. For example, personnel from a foreign trade office explained that they are spending most of their time providing information for a large multinational textile company, and therefore they give less attention to less experienced exporters. In light of this study's results, these types of priorities should be revised.

In addition, publicity should be especially increased for programs that are not sufficiently known: support to start exporting, consultancy, foreign trade offices and investment support. In any case, in order to be more efficient and effective, communication should be carried out in a segmented way, by informing each company about the programs fit to its internationalization stage. $^{7}$

Further, resources should be preferably allocated to programs with the highest impact: namely, sponsored international trade shows, trade missions, and information programs.

Other improvements pointed out by participants would reduce bureaucracy, increase flexibility, and strengthen coordination among the different EPOs.

In conclusion, programs have a positive effect, but the effect could be stronger and spread out to more companies if communication were improved, programs were more adapted to company needs, and program management were more flexible and efficient.

\section{Limitations and suggestions for further research}

The first limitation regards the use of correlations, which could imply possible type I error, incorrectly attributing impact to EPP use.

Additional limitations, which point to future research areas, are the following:

- The development of a specific analysis of the impact by industry.

- Including service companies in the survey and discovering their differences in impact and assistance requirements.

- Developing a complete longitudinal analysis, thus providing further confirmation of the causal effects of EPPs.

- Factor and regression analysis could also provide interesting results as to dynamics for groups and relationships among variables. They were not included in this study due to the logical length limitations of a single paper.

- The inclusion in this study of companies from a wide variety of industries may allow a higher generalization of the results than in previous research. Including sample companies from two different countries could enhance this generalization.

- Analyzing the specific needs regarding assistance of born global companies.

\section{Appendix A. Summary previous studies}

See Tables A1-A4.

\footnotetext{
${ }^{7}$ Clarke (1991) and Seringhaus (1986) also suggest that EPP publicity should be carried out with imagination, experience, enthusiasm and flexibility.
} 
Table A1

Studies on theoretical development and methodology.

\begin{tabular}{|c|c|c|c|c|}
\hline Title & Journal and author & Location & Study description & Findings \\
\hline $\begin{array}{l}\text { Export promotion } \\
\text { organization } \\
\text { emergence and } \\
\text { development: a } \\
\text { call to research }\end{array}$ & $\begin{array}{l}\text { International Marketing Review } \\
\text { AUTHOR: Gillespie } \\
\text { and Riddle (2004) }\end{array}$ & Global & $\begin{array}{l}\text { - Review of the literature. } \\
\text { Emphasis in the need to } \\
\text { develop more studies both at } \\
\text { macro and microeconomic } \\
\text { levels which evaluate export } \\
\text { promotion organizations } \\
\text { (EPOs) }\end{array}$ & $\begin{array}{l}\text { Proposals for future } \\
\text { research, methodology to be } \\
\text { used and policy evaluation }\end{array}$ \\
\hline $\begin{array}{l}\text { Understanding the } \\
\text { role of export } \\
\text { marketing } \\
\text { assistance: empirical } \\
\text { evidence and } \\
\text { research needs }\end{array}$ & $\begin{array}{l}\text { European Journal of } \\
\text { Marketing } \\
\text { AUTHOR: } \\
\text { Diamantopoulos } \\
\text { et al. (1993) }\end{array}$ & Global & $\begin{array}{l}\text { - Analysis of the role of export } \\
\text { promotion, centered basically } \\
\text { on the assistance offered by } \\
\text { the government. Empirical } \\
\text { contributions obtained from } \\
\text { literature review }\end{array}$ & $\begin{array}{l}\text { The degree of involvement, } \\
\text { attention and expectations } \\
\text { are key factors which } \\
\text { determine the level of use } \\
\text { and the impact of export } \\
\text { promotion programs }\end{array}$ \\
\hline $\begin{array}{l}\text { The role of informational } \\
\text { assistance in small firms }\end{array}$ & $\begin{array}{l}\text { International Small } \\
\text { Business Journal } \\
\text { AUTHOR: Seringhaus (1987) }\end{array}$ & Canada & $\begin{array}{l}\text { - Role of the assistance based } \\
\text { on the information in the } \\
\text { process of } \\
\text { internationalization of the } \\
\text { small enterprises }\end{array}$ & \\
\hline $\begin{array}{l}\text { A pilot evaluation of the } \\
\text { export marketing } \\
\text { research scheme }\end{array}$ & $\begin{array}{l}\text { British Overseas Trade Board, } \\
\text { Schanmark Export } \\
\text { Marketing Services } \\
\text { AUTHOR: Lemaghen (1987) }\end{array}$ & $\begin{array}{l}\text { United } \\
\text { Kingdom }\end{array}$ & $\begin{array}{l}\text { - Pilot evaluation on the } \\
\text { market research systems that } \\
\text { the government places at the } \\
\text { disposal of the English } \\
\text { exporters }\end{array}$ & \\
\hline $\begin{array}{l}\text { The impact of government } \\
\text { export marketing } \\
\text { assistance }\end{array}$ & $\begin{array}{l}\text { International Marketing Review } \\
\text { AUTHOR: Seringhaus (1986) }\end{array}$ & $\begin{array}{l}\text { Australia } \\
\text { and Canada }\end{array}$ & $\begin{array}{l}\text { - Literature review and } \\
\text { analysis of the different } \\
\text { methods used to study the } \\
\text { impact of the government } \\
\text { assistance programs on } \\
\text { companies. Transnational } \\
\text { comparison of the export } \\
\text { promotion services and their } \\
\text { use }\end{array}$ & $\begin{array}{l}\text { The relation between the } \\
\text { programs of assistance and } \\
\text { the success in exporting } \\
\text { cannot be demonstrated but } \\
\text { not ruled out either. } \\
\text { Programs must be studied } \\
\text { individually and together } \\
\text { with managers' attitude }\end{array}$ \\
\hline $\begin{array}{l}\text { The role of marketing } \\
\text { incentives in export } \\
\text { promotion: the } \\
\text { Uruguayan case }\end{array}$ & $\begin{array}{l}\text { AUTHOR: Brezzo and } \\
\text { Perkal (1983) }\end{array}$ & Uruguay & $\begin{array}{l}\text { - Identification of the type of } \\
\text { incentives considered } \\
\text { fundamental, its relationship } \\
\text { with companies strategic } \\
\text { planning and its application } \\
\text { formulae }\end{array}$ & $\begin{array}{l}\text { To achieve an increase in } \\
\text { exports is necessary to } \\
\text { create a system of incentives } \\
\text { (both economic and } \\
\text { marketing) based on the } \\
\text { needs of the companies and } \\
\text { of the industry, and on the } \\
\text { different stages of the } \\
\text { internationalization process }\end{array}$ \\
\hline $\begin{array}{l}\text { Export development } \\
\text { strategies }\end{array}$ & $\begin{array}{l}\text { Praeger } \\
\text { AUTHOR: } \\
\text { Czinkota (1982) }\end{array}$ & USA & $\begin{array}{l}\text { - Process of export and } \\
\text { influence of the government } \\
\text { assistance }\end{array}$ & \\
\hline
\end{tabular}

Table A2

Studies based on macroeconomic evaluations.

\begin{tabular}{llll}
\hline Title & Journal and author & $\begin{array}{l}\text { Location } \\
\text { (1) Study description }\end{array}$ & Findings \\
(2) Limitations
\end{tabular}


Table A3

Studies which evaluate specific programs.

\begin{tabular}{|c|c|c|c|c|}
\hline Title & $\begin{array}{l}\text { Journal and } \\
\text { author }\end{array}$ & Location & $\begin{array}{l}\text { (1) Study description } \\
\text { (2) Limitations }\end{array}$ & Findings \\
\hline $\begin{array}{l}\text { Trade promotion and SME } \\
\text { export performance }\end{array}$ & $\begin{array}{l}\text { International } \\
\text { Business Review } \\
\text { AUTHOR: } \\
\text { Brouthers and } \\
\text { Wilkinson } \\
(2006)\end{array}$ & Ohio (USA) & $\begin{array}{l}\text { - Evaluation of the relation between } \\
\text { the use by SMEs of a set of EPPs } \\
\text { (trade missions, sponsored trade } \\
\text { exhibitions and identification of } \\
\text { agents/distributors) financed by } \\
\text { states, and the satisfaction with } \\
\text { export success } \\
\text { - Limited sample (only } 105 \\
\text { companies) } \\
\text { - Impact measures based only on the } \\
\text { number of exports }\end{array}$ & $\begin{array}{l}\text { Use of sponsored trade fairs } \\
\text { and programs for the } \\
\text { identification of agents and } \\
\text { distributors are positively } \\
\text { related to SME satisfaction } \\
\text { with export success }\end{array}$ \\
\hline $\begin{array}{l}\text { Entrepreneurial climate and } \\
\text { U.S. state foreign trade } \\
\text { offices as predictors of } \\
\text { export success }\end{array}$ & $\begin{array}{l}\text { Journal of Small } \\
\text { Business } \\
\text { Management } \\
\text { AUTHOR: } \\
\text { Wilkinson } \\
(2006)\end{array}$ & USA & $\begin{array}{l}\text { - Analysis of the relationship } \\
\text { between State investment in foreign } \\
\text { trade offices, exports, and the } \\
\text { entrepreneurial climate } \\
\text { - Little multidimensionality (no } \\
\text { intermediate outcomes considered) } \\
\text { - Only a program evaluated; no } \\
\text { comparison between company } \\
\text { groups } \\
\text { - Only uses State aggregated data, } \\
\text { not on individual companies }\end{array}$ & $\begin{array}{l}\text { There is a positive relation } \\
\text { between the investment in } \\
\text { foreign trade offices and the } \\
\text { State's exports. This positive } \\
\text { relation is higher in those } \\
\text { States with a better } \\
\text { entrepreneurial climate } \\
\text { (measured by the GDP, the } \\
\text { employment and the income } \\
\text { per capita). }\end{array}$ \\
\hline $\begin{array}{l}\text { Evaluating export promotion } \\
\text { programs: UK overseas trade } \\
\text { missions and export performance }\end{array}$ & $\begin{array}{l}\text { Small Business } \\
\text { Economics } \\
\text { AUTHOR: } \\
\text { Spence (2003) }\end{array}$ & $\begin{array}{l}\text { United } \\
\text { Kingdom }\end{array}$ & $\begin{array}{l}\text { - Impact study of trade missions in } \\
\text { export performance depending on } \\
\text { company knowledge, features and } \\
\text { behavior } \\
\text { - The study does not compare } \\
\text { between groups and only studies a } \\
\text { specific program }\end{array}$ & $\begin{array}{l}\text { When participating in trade } \\
\text { missions, it is recommended } \\
\text { to obtain specific information, } \\
\text { know the competitors from } \\
\text { the new market and keep a } \\
\text { regular relationship with sales } \\
\text { contacts. Thus sales networks } \\
\text { will be extended and exports } \\
\text { will increase }\end{array}$ \\
\hline $\begin{array}{l}\text { The efficiency of government } \\
\text { promotion for outward FDI: } \\
\text { the intention to invest abroad }\end{array}$ & $\begin{array}{l}\text { Multinational } \\
\text { Business Review } \\
\text { AUTHOR: Duran } \\
\text { and Ubeda } \\
(2001)\end{array}$ & Spain & $\begin{array}{l}\text { - Evaluation of the impact of the } \\
\text { information provided by the ICEX to } \\
\text { the companies participating } \\
\text { Expotecnia trade shows, and their } \\
\text { tendency to foreign investment } \\
\text { - Only studies a specific promotion } \\
\text { instrument, and only the effects in a } \\
\text { form of internationalization (FDI) }\end{array}$ & $\begin{array}{l}\text { A higher internationalization, } \\
\text { through subsidiaries located } \\
\text { in other countries, originates a } \\
\text { higher predisposition to } \\
\text { foreign investment, as long as } \\
\text { business opportunities are } \\
\text { identified. This factor explains } \\
\text { more FDI than the impact of } \\
\text { the promotion program }\end{array}$ \\
\hline $\begin{array}{l}\text { An evaluation of state sponsored } \\
\text { promotion programs }\end{array}$ & $\begin{array}{l}\text { Journal of } \\
\text { Business } \\
\text { Research } \\
\text { AUTHOR: } \\
\text { Brouthers and } \\
\text { Wilkinson } \\
\text { (2000) }\end{array}$ & USA & $\begin{array}{l}\text { - Evaluation of the impact of two } \\
\text { specific export promotion programs } \\
\text { (trade missions and sponsored trade } \\
\text { shows) in export success, } \\
\text { considering high technology firms } \\
\text { - Only considers aggregate effect. } \\
\text { Doesnot study effects in individual } \\
\text { companies }\end{array}$ & $\begin{array}{l}\text { The participation in sponsored } \\
\text { trade shows relates positively } \\
\text { to the success in the exports } \\
\text { but not in trade missions } \\
\text { The same findings are } \\
\text { obtained for the exports of } \\
\text { high-tech companies }\end{array}$ \\
\hline $\begin{array}{l}\text { Management and performance } \\
\text { of international trade fair } \\
\text { exhibitors: government } \\
\text { stands vs. independent stands }\end{array}$ & $\begin{array}{l}\text { International } \\
\text { Marketing } \\
\text { Review } \\
\text { AUTHOR: } \\
\text { Seringhaus and } \\
\text { Rosson (1998) }\end{array}$ & Canada & $\begin{array}{l}\text { - Comparative analysis of the } \\
\text { companies which exhibit in } \\
\text { international fairs with and without } \\
\text { government help. Follow-up of } \\
\text { companies that took part in } 48 \text { int'. } \\
\text { fairs between } 1984 \text { and } 1986 \\
\text { - Only one program is evaluated }\end{array}$ & $\begin{array}{l}\text { Participating in fairs brings } \\
\text { about positive results, though } \\
\text { these depend on the level of } \\
\text { commitment of the company } \\
\text { towards the } \\
\text { internationalization process }\end{array}$ \\
\hline $\begin{array}{l}\text { Japan-based U.S. state } \\
\text { promotional offices as a form } \\
\text { of international contact }\end{array}$ & $\begin{array}{l}\text { Academy of } \\
\text { International } \\
\text { Business } \\
\text { AUTHOR: Martin } \\
(1996)\end{array}$ & USA & $\begin{array}{l}\text { - Analysis of the impact of the use of } \\
\text { promotional offices in Japan } \\
\text { - Only one instrument is evaluated } \\
\text { and uses very limited performance } \\
\text { outcomes }\end{array}$ & $\begin{array}{l}\text { There is no relationship } \\
\text { between exports and the use } \\
\text { of State Promotional Offices in } \\
\text { Japan. But other activities } \\
\text { such as city institutional } \\
\text { relationships are related to } \\
\text { exports }\end{array}$ \\
\hline $\begin{array}{l}\text { Different approaches to } \\
\text { foreign market entry between } \\
\text { users \& non-users of trade missions }\end{array}$ & $\begin{array}{l}\text { European } \\
\text { Journal of } \\
\text { Marketing } \\
\text { AUTHOR: } \\
\text { Seringhaus and } \\
\text { Mayer (1988) }\end{array}$ & Canada & $\begin{array}{l}\text { - Evaluation of the use of trade } \\
\text { missions as a way to enter in new } \\
\text { markets } \\
\text { - Only a program is evaluated, and } \\
\text { unlike in Seringhaus and Rosson } \\
\text { (1998), in which he was doing a } \\
\text { longitudinal analysis, here the study } \\
\text { is only cross sectional }\end{array}$ & $\begin{array}{l}\text { Markets are very different, } \\
\text { and although trade missions } \\
\text { are a very useful tool, they do } \\
\text { not solve all the barriers to } \\
\text { export }\end{array}$ \\
\hline
\end{tabular}


Table A3 (Continued)

\begin{tabular}{|c|c|c|c|c|}
\hline Title & $\begin{array}{l}\text { Journal and } \\
\text { author }\end{array}$ & Location & $\begin{array}{l}\text { (1) Study description } \\
\text { (2) Limitations }\end{array}$ & Findings \\
\hline $\begin{array}{l}\text { Government export mketing assistance } \\
\text { \& medium. sized Ontario } \\
\text { manufactur. firms: the role of trade } \\
\text { missions on firms off-shore market } \\
\text { involvement }\end{array}$ & $\begin{array}{l}\text { Phd dissertation, } \\
\text { York University } \\
\text { AUTHOR: } \\
\text { Seringhaus } \\
(1984)\end{array}$ & Canada & $\begin{array}{l}\text { - Role and impact of trade missions } \\
\text { organized by the government } \\
\text { - Study centered on only one } \\
\text { program: trade missions }\end{array}$ & \\
\hline $\begin{array}{l}\text { Nackfrageverhalten Kleiner und Mittlerer } \\
\text { Unternekmen nach } \\
\text { Aussenhandelsinformationen } \\
\text { und Beratung }\end{array}$ & $\begin{array}{l}\text { Verlag, Schwartz } \\
\text { \& Co., Beitraege } \\
\text { zur } \\
\text { Mittelstands- } \\
\text { orschung } \\
\text { AUTHOR: } \\
\text { Schwarting et al. } \\
(1982)\end{array}$ & $\begin{array}{l}\text { West } \\
\text { Germany }\end{array}$ & $\begin{array}{l}\text { - Demand of advice and information } \\
\text { from German exporting SMEs }\end{array}$ & \\
\hline
\end{tabular}

Table A4

Studies which evaluate export promotion programs collectively.

\begin{tabular}{|c|c|c|c|c|}
\hline Title & $\begin{array}{l}\text { Journal and } \\
\text { author }\end{array}$ & Location & $\begin{array}{l}\text { (1) Study description } \\
\text { (2) Limitations }\end{array}$ & Findings \\
\hline $\begin{array}{l}\text { Impact of export } \\
\text { promotion programs } \\
\text { on firm competencies, } \\
\text { strategies and performance }\end{array}$ & $\begin{array}{l}\text { International } \\
\text { Marketing } \\
\text { Review } \\
\text { AUTHOR: } \\
\text { Francis and } \\
\text { Collins-Dodd } \\
(2004)\end{array}$ & Canada & $\begin{array}{l}\text { - Impact of the programs in the } \\
\text { results, the strategies and the } \\
\text { competencies of the Canadian high- } \\
\text { tech companies, depending on their } \\
\text { export involvement. } \\
\text { Internationalization model with four } \\
\text { stages: pre-exporting, sporadic, } \\
\text { active and majority exporters } \\
\text { - Only cross sectional study and } \\
\text { without differentiation of the impact } \\
\text { for each type of program }\end{array}$ & $\begin{array}{l}\text { Use of EPPs is positive for } \\
\text { companies with little experience, } \\
\text { both if they export sporadically or } \\
\text { regularly } \\
\text { The impact is lower for } \\
\text { companies with more experience }\end{array}$ \\
\hline $\begin{array}{l}\text { The evaluation of the public } \\
\text { promotion of the } \\
\text { internationalization: } \\
\text { implications on the exporting } \\
\text { companies of the Comunidad } \\
\text { Valenciana }\end{array}$ & $\begin{array}{l}\text { PhD dissertation } \\
\text { AUTHOR: Fayos } \\
(2003)\end{array}$ & $\begin{array}{l}\text { Comunidad } \\
\text { Valenciana } \\
\text { (Spain) }\end{array}$ & $\begin{array}{l}\text { - Analyses company satisfaction and } \\
\text { their level of use, effectiveness and } \\
\text { impact of the programs. The study } \\
\text { segments companies depending on } \\
\text { different features in order to see their } \\
\text { influence in these evaluation } \\
\text { elements } \\
\text { - The study is cross sectional and } \\
\text { uses only subjective measures of } \\
\text { impact, and only from program } \\
\text { users. Direct investment is not } \\
\text { considered when segmenting by } \\
\text { export stages }\end{array}$ & $\begin{array}{l}\text { Companies need external support } \\
\text { to initiate internationalization } \\
\text { processes } \\
\text { In general, managers expect more } \\
\text { from programs than what they } \\
\text { offer. Managers' attitudes and } \\
\text { aptitudes are critical and } \\
\text { programs should take them into } \\
\text { consideration } \\
\text { Differences between companies } \\
\text { are higher if compared depending } \\
\text { on the industry than the } \\
\text { internationalization stage }\end{array}$ \\
\hline $\begin{array}{l}\text { The effect of export assistance } \\
\text { program usage on export } \\
\text { performance: a contingency } \\
\text { explanation }\end{array}$ & $\begin{array}{l}\text { Journal of } \\
\text { International } \\
\text { Marketing } \\
\text { AUTHOR: } \\
\text { Gençtürk and } \\
\text { Kotabe (2001) }\end{array}$ & USA & $\begin{array}{l}\text { - Creation of a model of exporting } \\
\text { process and its empirical evaluation. } \\
\text { Study of the differences of } \\
\text { organization, functioning and } \\
\text { behavior among exporting } \\
\text { companies, in order to determine the } \\
\text { factors for companies' exporting } \\
\text { success } \\
\text { - Only cross sectional study }\end{array}$ & $\begin{array}{l}\text { The level of commitment of the } \\
\text { company is a key factor for export } \\
\text { success } \\
\text { The impact of export promotion } \\
\text { programs depends on the } \\
\text { dimension of performance } \\
\text { studied: efficiency, effectiveness } \\
\text { or competitive position }\end{array}$ \\
\hline $\begin{array}{l}\text { UK SME's awareness, use, and } \\
\text { perceptions of selected } \\
\text { government export assistance } \\
\text { An investigation into effect } \\
\text { of ethnicity }\end{array}$ & $\begin{array}{l}\text { International } \\
\text { Journal of } \\
\text { Entrepreneurial } \\
\text { Behaviour \& } \\
\text { Research } \\
\text { AUTHOR: Crick } \\
\text { and Chaudhry } \\
\text { (2000) }\end{array}$ & $\begin{array}{l}\text { United } \\
\text { Kingdom }\end{array}$ & $\begin{array}{l}\text { - Comparative study between the } \\
\text { companies with Asian and native } \\
\text { (from UK) managers regarding their } \\
\text { awareness, perception and use of } \\
\text { Government Export Assistance } \\
\text { - Measures of impact limited to } \\
\text { measures of use and perception }\end{array}$ & $\begin{array}{l}\text { There are differences between the } \\
\text { two groups of companies, with } \\
\text { Asian and native managers, in } 9 \\
\text { out of } 12 \text { programs studied } \\
\text { Asian managers, in general, have } \\
\text { higher program awareness }\end{array}$ \\
\hline
\end{tabular}


Table A4 (Continued)

\begin{tabular}{|c|c|c|c|c|}
\hline Title & $\begin{array}{l}\text { Journal and } \\
\text { author }\end{array}$ & Location & $\begin{array}{l}\text { (1) Study description } \\
\text { (2) Limitations }\end{array}$ & Findings \\
\hline $\begin{array}{l}\text { Profiling managers to improve } \\
\text { export promotion targeting }\end{array}$ & $\begin{array}{l}\text { Journal of } \\
\text { International } \\
\text { Business Studies } \\
\text { AUTHOR: Gray } \\
\text { (1997) }\end{array}$ & $\begin{array}{l}\text { New } \\
\text { Zeland }\end{array}$ & $\begin{array}{l}\text { - Study on whether managers with a } \\
\text { positive attitude towards } \\
\text { international business and with } \\
\text { knowledge on the topic are also more } \\
\text { expert and trained. Determination of } \\
\text { a typology of managers based on the } \\
\text { attitude and knowledge as } \\
\text { segmentation variables for EPPs } \\
\text { - Centered exclusively on managers } \\
\text { and their opinions. Does not take into } \\
\text { consideration the company's } \\
\text { features and results }\end{array}$ & $\begin{array}{l}\text { Although managers with better } \\
\text { internationalization performance } \\
\text { have usually more experience, } \\
\text { they don't differentiate from the } \\
\text { rest for having received more } \\
\text { specific education } \\
\text { Experience is more important } \\
\text { than academic education }\end{array}$ \\
\hline $\begin{array}{l}\text { Small businesses' motives for } \\
\text { exporting. The effect of } \\
\text { internationalization }\end{array}$ & $\begin{array}{l}\text { Journal of } \\
\text { Marketing } \\
\text { Practice } \\
\text { AUTHOR: Crick } \\
\text { and Chaudhry } \\
\text { (1997) }\end{array}$ & $\begin{array}{l}\text { United } \\
\text { Kingdom }\end{array}$ & $\begin{array}{l}\text { - Study of } 22 \text { possible motivations of } \\
\text { the companies to export in the } \\
\text { different levels of the exporting } \\
\text { process. It includes cases of } \\
\text { companies with national and Asian } \\
\text { managers. Model of } \\
\text { internationalization process with } 8 \\
\text { stages (based on Campbell, 1987) } \\
\text { - Only it is considered the effect of } \\
\text { programs in an indirect way, as an } \\
\text { additional internationalization } \\
\text { factor }\end{array}$ & $\begin{array}{l}\text { SMEs in different stages of the } \\
\text { internationalization process have } \\
\text { different motivations for } \\
\text { exporting } \\
\text { Promotion programs and export } \\
\text { incentives are valued as little } \\
\text { motivating }\end{array}$ \\
\hline $\begin{array}{l}\text { Determinants of export } \\
\text { performance in a European context }\end{array}$ & $\begin{array}{l}\text { European } \\
\text { Journal of } \\
\text { Marketing } \\
\text { AUTHOR: } \\
\text { Katsikeas et al. } \\
\text { (1996) }\end{array}$ & Greece & $\begin{array}{l}\text { - Study of the factors that affect } \\
\text { success in exports: company size, } \\
\text { experience, level of motivation, } \\
\text { perception of the barriers to the } \\
\text { export, competitive position, and } \\
\text { resources dedicated to exports } \\
\text { - Export performance measured only } \\
\text { on the basis of managers' opinions }\end{array}$ & $\begin{array}{l}\text { A positive relationship cannot be } \\
\text { proved between export } \\
\text { performance and size or } \\
\text { experience, but it can with } \\
\text { motivation and with an } \\
\text { appropriate use of the available } \\
\text { resources } \\
\text { The government has a crucial role } \\
\text { in export increase }\end{array}$ \\
\hline $\begin{array}{l}\text { Export assistance } \\
\text { Another look at whether } \\
\text { we are supporting the } \\
\text { best programmes }\end{array}$ & $\begin{array}{l}\text { International } \\
\text { Marketing } \\
\text { Review } \\
\text { AUTHOR: Crick } \\
\text { and Czinkota } \\
\text { (1995) }\end{array}$ & $\begin{array}{l}\text { USA and } \\
\text { United } \\
\text { Kingdom }\end{array}$ & $\begin{array}{l}\text { - Study of the attitudes and the } \\
\text { needs of the exporters based on the } \\
\text { aspects that they believed important } \\
\text { for the client. Research based on UK } \\
\text { companies, using as comparative } \\
\text { information the findings of a first } \\
\text { study in the US } \\
\text { - It's a transnational study but the } \\
\text { study in each country was carried } \\
\text { out in different moments, which } \\
\text { decreases the validity of the } \\
\text { conclusions }\end{array}$ & $\begin{array}{l}\text { In the US the final product is what } \\
\text { exporters believe clients value } \\
\text { more } \\
\text { Findings in the UK are consistent } \\
\text { with those of the US. Both obtain } \\
\text { differences between the factors } \\
\text { that the exporters believe that are } \\
\text { important for the clients and } \\
\text { those who are expected from the } \\
\text { programs } \\
\text { Managers know little public } \\
\text { export promotion programs }\end{array}$ \\
\hline $\begin{array}{l}\text { An investigation into } \\
\text { the targeting of UK } \\
\text { export assistance }\end{array}$ & $\begin{array}{l}\text { European } \\
\text { Journal of } \\
\text { Marketing } \\
\text { AUTHOR: Crick } \\
\text { (1995) }\end{array}$ & $\begin{array}{l}\text { United } \\
\text { Kingdom }\end{array}$ & $\begin{array}{l}\text { - Description of the process of } \\
\text { internationalization in } 8 \text { stages. } \\
\text { Study of the features, the perceived } \\
\text { important factors for the clients, the } \\
\text { keys to export, the needs, the } \\
\text { problems and the demands of help of } \\
\text { the companies in different } \\
\text { internationalization stages } \\
\text { - Only evaluates the programs } \\
\text { regarding their relationship with } \\
\text { intermediate results, not final }\end{array}$ & $\begin{array}{l}\text { There are differences among } \\
\text { companies depending on the } \\
\text { eight stages of the } \\
\text { internationalization process } \\
\text { For the government it's more } \\
\text { practical to uses a model with less } \\
\text { stages in order to adapt the } \\
\text { programs }\end{array}$ \\
\hline $\begin{array}{l}\text { Factors associated with } \\
\text { effective use of export } \\
\text { assistance }\end{array}$ & $\begin{array}{l}\text { Journal of } \\
\text { International } \\
\text { Marketing } \\
\text { AUTHOR: Singer } \\
\text { and Czinkota } \\
(1994)\end{array}$ & $\begin{array}{l}\text { Minnesota } \\
\text { (USA) }\end{array}$ & $\begin{array}{l}\text { - Study of the factors which affect } \\
\text { the effective use of export assistance: } \\
\text { program type, company's export } \\
\text { stage, managers' commitment, type } \\
\text { of performance dimension and } \\
\text { relationship between these factors } \\
\text { - It's a study of segmentation of the } \\
\text { programs. No impact analysis }\end{array}$ & $\begin{array}{l}\text { There is not relationship between } \\
\text { the type of results, the type of } \\
\text { service used, the } \\
\text { internationalization level or } \\
\text { company size } \\
\text { Instead, there is a relationship } \\
\text { between number of programs } \\
\text { used and managers' implication } \\
\text { with performance level }\end{array}$ \\
\hline
\end{tabular}


Table A4 (Continued)

\begin{tabular}{|c|c|c|c|c|}
\hline Title & $\begin{array}{l}\text { Journal and } \\
\text { author }\end{array}$ & Location & $\begin{array}{l}\text { (1) Study description } \\
\text { (2) Limitations }\end{array}$ & Findings \\
\hline $\begin{array}{l}\text { Public sector promotion of } \\
\text { exports: a needs-based } \\
\text { approach }\end{array}$ & $\begin{array}{l}\text { Journal of } \\
\text { Business } \\
\text { Research } \\
\text { AUTHOR: Naidu } \\
\text { and Rao (1993) }\end{array}$ & USA & $\begin{array}{l}\text { - Study of the differences and the } \\
\text { needs of assistance between } \\
\text { companies in different stages of the } \\
\text { internationalization process. Use of a } \\
\text { process internationalization model } \\
\text { with four stages. Proposes possible } \\
\text { strategies to minimize the } \\
\text { differences } \\
\text { - Only cross sectional analysis }\end{array}$ & $\begin{array}{l}\text { Companies have different needs } \\
\text { depending on their } \\
\text { internationalization stage and so } \\
\text { export promotion assistance } \\
\text { should consider these differences }\end{array}$ \\
\hline $\begin{array}{l}\text { State government promotion } \\
\text { of manufacturing exports: } \\
\text { a gap analysis }\end{array}$ & $\begin{array}{l}\text { Journal of } \\
\text { International } \\
\text { Business Studies } \\
\text { AUTHOR: } \\
\text { Czinkota and } \\
\text { Kotabe (1992) }\end{array}$ & USA & $\begin{array}{l}\text { - Relation between companies' } \\
\text { assistance needs and their } \\
\text { internationalization stage } \\
\text { - Only considers exports and not } \\
\text { direct investment' }\end{array}$ & $\begin{array}{l}\text { Programs do not always adapt to } \\
\text { companies' needs, and these } \\
\text { change depending on the } \\
\text { internationalization stage }\end{array}$ \\
\hline $\begin{array}{l}\text { The impact of government } \\
\text { export marketing } \\
\text { assistance }\end{array}$ & $\begin{array}{l}\text { International } \\
\text { Marketing } \\
\text { Review } \\
\text { AUTHOR: } \\
\text { Seringhaus and } \\
\text { Botschen (1991) }\end{array}$ & $\begin{array}{l}\text { Canada and } \\
\text { Australia }\end{array}$ & $\begin{array}{l}\text { - Transnational comparison of the } \\
\text { export promotion systems and their } \\
\text { use. Evaluation of their usefulness } \\
\text { according to managers } \\
\text { - The study doesn't use objective } \\
\text { information, only opinions }\end{array}$ & $\begin{array}{l}\text { Managers wish programs were } \\
\text { better segmented and adapted, } \\
\text { and with a higher participation of } \\
\text { the private sector }\end{array}$ \\
\hline $\begin{array}{l}\text { Evaluation of export promotion } \\
\text { measures: A survey of Scottish } \\
\text { food and drink exporters }\end{array}$ & $\begin{array}{l}\text { In Seringhaus, } \\
\text { Rosson (Eds.), } \\
\text { Export } \\
\text { development } \\
\text { and promotion: } \\
\text { the role of public } \\
\text { organisations } \\
\text { AUTHOR: } \\
\text { Diamantopoulos } \\
\text { et al. (1991) }\end{array}$ & $\begin{array}{l}\text { Scotland } \\
\text { (United } \\
\text { Kingdom) }\end{array}$ & $\begin{array}{l}\text { - Study on the use and evaluation of } \\
\text { export promotion, by managers. } \\
\text { Determination of the differences } \\
\text { between companies which receive } \\
\text { support and those which do not } \\
\text { - The sample is too small ( } 48 \\
\text { companies) and without objective } \\
\text { measurements }\end{array}$ & \\
\hline $\begin{array}{l}\text { An empirical investigation } \\
\text { of export promotion programs }\end{array}$ & $\begin{array}{l}\text { Columbia } \\
\text { Journal of World } \\
\text { Business } \\
\text { AUTHOR: } \\
\text { Chokar and } \\
\text { Kedia (1986) }\end{array}$ & $\begin{array}{l}\text { Louisiana } \\
\text { (USA) }\end{array}$ & $\begin{array}{l}\text { - Evaluation of the use and the } \\
\text { benefits of } 17 \text { EPPs from exporting } \\
\text { and non-exporting companies } \\
\text { - Cross sectional study and without } \\
\text { use of objective measures }\end{array}$ & $\begin{array}{l}\text { Facilitating the access and the } \\
\text { information about the available } \\
\text { programs should be a priority of } \\
\text { EPOs }\end{array}$ \\
\hline $\begin{array}{l}\text { Empirical investigation of } \\
\text { awareness, use and impact } \\
\text { of export marketing support by } \\
\text { government in manufacturing } \\
\text { firms }\end{array}$ & $\begin{array}{l}\text { Proceedings of } \\
\text { XVth Annual } \\
\text { Conference of } \\
\text { the European } \\
\text { Academy of } \\
\text { Marketing } \\
\text { AUTHOR: } \\
\text { Seringhaus } \\
\text { (1986) }\end{array}$ & Canada & $\begin{array}{l}\text { - Measurement of awareness, use } \\
\text { and impact of export promotion } \\
\text { programs in manufacturing firms } \\
\text { - Measurement only using } \\
\text { perceptions and not objective results }\end{array}$ & \\
\hline $\begin{array}{l}\text { Information acquisition } \\
\text { and export entry decisions } \\
\text { in small firms }\end{array}$ & $\begin{array}{l}\text { Journal of } \\
\text { Business } \\
\text { Research } \\
\text { AUTHOR: Reid } \\
(1984)\end{array}$ & $\begin{array}{l}\text { Ontario, } \\
\text { Canada }\end{array}$ & $\begin{array}{l}\text { - Processes of information } \\
\text { acquisition, strategy and export } \\
\text { decisions in small companies } \\
\text { - It does not distinguish groups of } \\
\text { companies and it's only based on } \\
\text { perceptions }\end{array}$ & $\begin{array}{l}\text { Companies have multiple sources } \\
\text { of information and this will be a } \\
\text { key element when taking } \\
\text { decisions regarding exports }\end{array}$ \\
\hline $\begin{array}{l}\text { Export information sources } \\
\text { - a study of their usage \& utility }\end{array}$ & $\begin{array}{l}\text { International } \\
\text { Marketing } \\
\text { Review } \\
\text { AUTHOR: } \\
\text { Walters (1983) }\end{array}$ & USA & $\begin{array}{l}\text { - Role and use of information about } \\
\text { exports from external sources } \\
\text { - Cross sectional study, without } \\
\text { distinction between groups and } \\
\text { based only on subjective } \\
\text { information. Study of the programs } \\
\text { only on an indirect way }\end{array}$ & $\begin{array}{l}\text { At the beginning of the exporting } \\
\text { process is when companies need } \\
\text { more information, but also when } \\
\text { they can dedicate fewer resources } \\
\text { to obtain it. Personal information } \\
\text { is the most valuable type }\end{array}$ \\
\hline $\begin{array}{l}\text { Communication and competence } \\
\text { in private sector involvement } \\
\text { in international trade policy }\end{array}$ & $\begin{array}{l}\text { In Czinkota (Ed.), } \\
\text { Export } \\
\text { promotion: the } \\
\text { public \& private } \\
\text { sector } \\
\text { interaction } \\
\text { AUTHOR: Singh } \\
\text { (1983) }\end{array}$ & India & $\begin{array}{l}\text { - Implication of the private sector in } \\
\text { trade policies } \\
\text { - A study of impact is not carried out } \\
\text { and does not distinguish between } \\
\text { groups of companies }\end{array}$ & \\
\hline
\end{tabular}




\begin{tabular}{|c|c|c|c|c|}
\hline Title & $\begin{array}{l}\text { Journal and } \\
\text { author }\end{array}$ & Location & $\begin{array}{l}\text { (1) Study description } \\
\text { (2) Limitations }\end{array}$ & Findings \\
\hline $\begin{array}{l}\text { Government-industry relations } \\
\text { in exporting: lessons } \\
\text { from the UK }\end{array}$ & $\begin{array}{l}\text { In Czinkota (Ed.), } \\
\text { export } \\
\text { promotion: the } \\
\text { public \& private } \\
\text { sector interaction } \\
\text { AUTHOR: } \\
\text { Buckley (1983) }\end{array}$ & $\begin{array}{l}\text { United } \\
\text { Kingdom }\end{array}$ & $\begin{array}{l}\text { - Description of the functioning of } \\
\text { the government agencies. Review } \\
\text { and perception of the export } \\
\text { promotion programs and assistance } \\
\text { - Does not analyze the effects of the } \\
\text { programs in companies' } \\
\text { performance }\end{array}$ & $\begin{array}{l}\text { Besides investing resources in } \\
\text { export promotion, the government } \\
\text { should improve communication } \\
\text { and create more suitable programs, } \\
\text { because companies doubt on their } \\
\text { usefulness }\end{array}$ \\
\hline $\begin{array}{l}\text { Effectiveness of government } \\
\text { export assistance for U.S. } \\
\text { small-sized manufacturers: } \\
\text { some further evidence }\end{array}$ & $\begin{array}{l}\text { International } \\
\text { Marketing } \\
\text { Review } \\
\text { AUTHOR: } \\
\text { Albaum } \\
\text { (Autumn 1983) }\end{array}$ & $\begin{array}{l}\text { Oregon, } \\
\text { Washington } \\
\text { and Idaho } \\
\text { states (USA) }\end{array}$ & $\begin{array}{l}\text { - Evaluation of the level of } \\
\text { awareness, use and perception of the } \\
\text { value of the export assistance from } \\
\text { small-sized manufacturers } \\
\text { - Effectiveness of the programs } \\
\text { valued only using subjective } \\
\text { measurements and not considering } \\
\text { the impact in results }\end{array}$ & $\begin{array}{l}\text { The government values positively } \\
\text { export promotion programs, but } \\
\text { companies consider them neither } \\
\text { useful nor profitable } \\
\text { There is little communication } \\
\text { between companies and the } \\
\text { government }\end{array}$ \\
\hline $\begin{array}{l}\text { Export assistance: are } \\
\text { we supporting the } \\
\text { best programs? }\end{array}$ & $\begin{array}{l}\text { Columbia } \\
\text { Journal of World } \\
\text { Business } \\
\text { AUTHOR: } \\
\text { Czinkota and } \\
\text { Ricks (1981) }\end{array}$ & USA & $\begin{array}{l}\text { - Managers' perception and opinion } \\
\text { about export assistance } \\
\text { - Study based only on subjective } \\
\text { information or managers' perceptions }\end{array}$ & \\
\hline $\begin{array}{l}\text { Business attitudes to } \\
\text { government export } \\
\text { services \& export } \\
\text { marketing behaviour }\end{array}$ & $\begin{array}{l}\text { New Zealand } \\
\text { Journal of } \\
\text { Business } \\
\text { AUTHOR: } \\
\text { Cullwick and } \\
\text { Mellallieu (1981) }\end{array}$ & $\begin{array}{l}\text { New } \\
\text { Zealand }\end{array}$ & $\begin{array}{l}\text { - Analysis of the attitude of managers } \\
\text { from exporting companies regarding } \\
\text { Government export services, and the } \\
\text { way they use them. Determination of } \\
\text { the profile of the exporting character } \\
\text { of the studied companies } \\
\text { - Study of attitudes with regard to } \\
\text { programs, but not of their impact }\end{array}$ & $\begin{array}{l}\text { Having objective and trustworthy } \\
\text { information on the markets and } \\
\text { business opportunities abroad is } \\
\text { a key factor for the success of the } \\
\text { exports. Government must be } \\
\text { responsible for delivering it }\end{array}$ \\
\hline $\begin{array}{l}\text { Export promotion } \\
\text { policy - a new approach }\end{array}$ & $\begin{array}{l}\text { Australian } \\
\text { Journal of } \\
\text { Management } \\
\text { AUTHOR: Welch } \\
\text { and } \\
\text { Wiedersheim- } \\
\text { Paul (1979) }\end{array}$ & $\begin{array}{l}\text { United } \\
\text { Kingdom }\end{array}$ & $\begin{array}{l}\text { - Approach to export promotion } \\
\text { policy for companies in the stages of } \\
\text { pre-exports and beginning of exports } \\
\text { - It does not differentiate between } \\
\text { groups of companies and only } \\
\text { analyzes one aspect of the programs: } \\
\text { motivating companies to start } \\
\text { exporting }\end{array}$ & $\begin{array}{l}\text { In the initial stages of the exporting } \\
\text { process financial help is required, } \\
\text { but the key factors are managers' } \\
\text { attitude, their knowledge and the } \\
\text { advice that they receive }\end{array}$ \\
\hline $\begin{array}{l}\text { Measuring the gains from } \\
\text { government export } \\
\text { promotion }\end{array}$ & $\begin{array}{l}\text { European } \\
\text { Journal of } \\
\text { Marketing } \\
\text { AUTHOR: } \\
\text { Pointon (1978) }\end{array}$ & $\begin{array}{l}\text { Greater } \\
\text { London } \\
\text { Area (UK) }\end{array}$ & $\begin{array}{l}\text { - A quantitative method is explored } \\
\text { in order to establish the value or } \\
\text { usefulness of export promotion } \\
\text { - Analyzes the cost-benefit } \\
\text { relationship of government's } \\
\text { assistance } \\
\text { - It does not distinguish between } \\
\text { groups of companies, and carries out } \\
\text { only a quantitative evaluation of the } \\
\text { impact }\end{array}$ & $\begin{array}{l}\text { Bges }=\text { Xic } * \text { Mc } * \text { RCc } * \text { FEc } \\
\text { Bges: assistance benefits } \\
\text { Xic: effects in sales volume } \\
\text { Mc: import coefficient } \\
\text { RCc: ressource cost } \\
\text { Fec: currency exchange rate }\end{array}$ \\
\hline $\begin{array}{l}\text { Exploring the impact of } \\
\text { governmental export } \\
\text { subsidies }\end{array}$ & $\begin{array}{l}\text { European Journal } \\
\text { of Marketing } \\
\text { AUTHOR: } \\
\text { Gronhaug and } \\
\text { Lorentzen (1983) }\end{array}$ & Norway & $\begin{array}{l}\text { - Measurement of the impact of } \\
\text { government export subsidies } \\
\text { through the formula: } \\
R_{e}=\sum_{i} q_{i} p_{i}-\sum_{i} a_{j} c_{j} \\
R_{e}: \text { export contribution } \\
q_{i} \text { : quantity of exported product } \\
p_{i}: \text { product prices } \\
a_{j}: \text { use of export assistance } \\
c_{j} \text { : cost of export activities } \\
- \text { Only analyzes direct subsidies and } \\
\text { no other types of assistance. }\end{array}$ & $\begin{array}{l}\text { Export barriers are higher for } \\
\text { small companies, which are less } \\
\text { diversified, have less capacity to } \\
\text { obtain information and means to } \\
\text { overcome the obstacles }\end{array}$ \\
\hline $\begin{array}{l}\text { Canadian small business abroad: } \\
\text { opportunities, aids and } \\
\text { experiences }\end{array}$ & $\begin{array}{l}\text { Business } \\
\text { Quarterly } \\
\text { AUTHOR: Mayer } \\
\text { and Flynn (1973) }\end{array}$ & Canada & $\begin{array}{l}\text { - Managers' experience and attitude } \\
\text { regarding export promotion } \\
\text { - It's a summary of opinions, without } \\
\text { distinction between groups and } \\
\text { without measuring the impact }\end{array}$ & $\begin{array}{l}\text { Foreign markets offer } \\
\text { opportunities to Canadian small } \\
\text { enterprises. Although programs } \\
\text { help to reduce export barriers, } \\
\text { managers prefer direct and } \\
\text { personal market experience }\end{array}$ \\
\hline
\end{tabular}




\section{References}

Albaum, G. (1983). Efectiveness of government export assistance for U.S. smaller-sized Manufacturers: Some further evidence. International Marketing Review, 6875.

Alonso, J. A., \& Donoso, V. (1996). Obstáculos a la internacionalización and políticas públicas de promoción. El caso de España. Papeles de Economía Española, 66, $124-143$.

Archer, J. N. (1971). A new look for CSD management services. OEM Bulletin, February, 4-13.

Armah, B., \& Epperson, J. (1997). Export demand for U.S. orange juice. Impacts of U.S. export promotion programs. Agribusiness, 13 , 1-10.

Barnhart, J. (1968). Export profitability: An analysis among Indiana firms. Unpublished PhD, Indiana University.

Barret, N., \& Wilkinson, I. (1986). Australian management's attitudes to exporting - Past and present. Paper presentado en la market research society of Australia's annual conference, Canberra, 1986.

Brewer, P. (2009). Australia's export promotion program: Is it effective? Australia Journal of Management, 34(1), 125-142.

Brezzo, R., \& Perkal, I. (1983). The role of marketing incentives in export promotion: The Uruguaian case. In M. Czinkota (Ed.), Export promotion, the public and private sector interaction (pp. 51-65). New York: Praeger Publishers.

Brooks, M., \& Rosson, P. (1982). A study of export behavior of small- and medium-sized manufacturing firms in three Canadian provinces. In M. Czinkota \& G. Tesar (Eds.), Export management (pp. 39-52). New York: Praeger.

Brouthers, L. E., \& Wilkinson, T. J. (2006). Trade promotion and SME export performance. International Business Review, 15, 233-252.

Brouthers, L. E., \& Wilkinson, T. J. (2000). An evaluation of state sponsored promotion programs. Journal of Business Research, 47, 229-236.

Buckley, P. (1983). Government-industry relations in exporting: Lessons from the United Kingdom. In M. R. Czinkota (Ed.), Export promotion, the public and private sector interaction (pp. 51-65). New York: Praeger Publishers.

Calderón, H., \& Fayos, T. (2004). Análisis de la Relación entre el Compromiso Exportador y las Ayudas a la Internacionalización de las Empesas. Investigaciones Europeas de Dirección y Economía de la Empresa, 10(2), 201-220.

Cavusgil, S. T. (1983). Success factors in export marketing: An empirical analysis. Journal of International Marketing and Marketing Research, 8(2), 63-73.

Chokar, J. S., \& Kedia, B. L. (1986). An empirical investigation of export promotion programs. Columbia Journal of World Business, 13-20.

Clarke, W. M. (1991). Changing small firm's attitudes to exporting: A case study of successful intervention. Export development and promotion: The role of public organizations, Kluwer Academic Publishers. (pp. 275-300).

Crick, D., \& Chaudhry, S. (2000). UK SME's awareness, use, and perceptions of selected government export assistance. An investigation into the effect of ethnicity. International Journal of Entrepreneurial Behaviour and Research, 6(2), 72-89.

Crick, D., \& Chaudhry, S. (1997). Small businesses' motives for exporting. The effect of internationalization. Journal of Marketing Practice: Applied Marketing Science, 3(3), 156-170.

Crick, D. (1997). UK SMEs' awareness, use, and perceptions of selected government export assistance: An investigation into the effect of the internationalisation process. International Trade Journal, X1(1), 135-167.

Crick, D., \& Czinkota, M. R. (1995). Export assistance. Another look at whether we are supporting the best programmes. International Marketing Review, 12(3), 6172.

Crick, D. (1995). An investigation into the targeting of UK export assistance. European Journal of Marketing, 29(8), 76-94.

Coughlin, C. C., \& Cartwright, P. A. (1987). An examination of state foreign export promotion and manufacturing exports. Journal of Regional Science, 27, 439-449.

Cullwick, T. D. C., \& Mellallieu, J. P. (1981). Business attitudes to government export services \& export marketing behaviour. New Zealand Journal of Business, 3, 3354.

Cunningham, M. T., \& Spigel, R. I. (1971). A study in successful exporting. British Journal of Marketing, 5: 2-12 (Spring)

Czinkota, M. R., \& Ricks, D. A. (1981). Export assistance: Are we supporting the best programs? Columbia Journal of World Business, Summer(16), 73-78.

Czinkota, M. R. (1996). Why national export promotions? International Trade Forum, 2, 10-13 28.

Czinkota, M. R., \& Kotabe, M. (1992). State government promotion of manufacturing exports: A gap analysis. Journal of International Business Studies, 23(4), 637_ 658.

Czinkota, M. R. (1982a). Export development strategies. New York, NY: Praeger.

Czinkota, M. R. (1982b). An evaluation of the effectiveness of US export promotion efforts. In M. Czinkota \& G. Tesar (Eds.), Export policy: A global assessment (pp. 63-71). New York, NY: Praegar.

Czinkota, M. R., \& Johnston, W. J. (1983). Exporting: does sales volume make a difference. Journal of International Business Studies, 14, $147-153$.

Davar, S., \& Wheeler, C. (1992). Measuring the impact of government export promotion programmes on business performance at the firm level (pp. 1525-1534).

Diamantopoulos, A., Schlegelmilch, B. B., \& Tse, K. Y. (1993). Understanding the role of export marketing assistance: Empirical evidence and research needs. European Journal of Marketing, 27(4), 5-18.

Diamantopoulos, A., Schlegelmilch, B. B., \& Inglis, K. (1991). Evaluation of export promotion measures: A survey of Scottish Food and Drink Exporters. Export development and promotion: The role of public organizations, Kluwer Academic Publishers. (pp. 190-214).

Diamantopoulos, A., \& Inglis, K. (1988). Identifying differences between high- and low-involvement exporters. International Marketing Review, 5(2), 52-60.

Dichtl, E., Koeglmayr, H. G., \& Muller, S. (1986). Identifying export potential: A comparative analysis of German and Japanese firms. In S. T. Cavusgil (Ed.), Advances in international marketing (pp. 233-254). Greenwich, Conn. JAI Press.

Dillman, D. A. (2002). Navigating the rapids of change: Some observations on survey methodology in the early 21 st century. Public Opinion Quarterly, 66(3), 473494.

Duran, J. J., \& Ubeda, F. (2001). The efficiency of government promotion for outward FDI: The intention to invest abroad. Multinational Business Review, 24-32.

Fayos, T. (2003), La Evaluación de la Promoción Pública de la Internacionalización: Implicaciones sobre las Empresas Exportadoras de la Comunidad Valenciana. PhD dissertation, Universidad de Valencia.

Francis, J., \& Collins-Dodd, C. (2004). Impact of export promotion programs on firm competencies, strategies and performance - The case of Canadian high-tech SMEs. International Marketing Review, 4(5), 474-495.

Gençtürk, E. F., \& Kotabe, M. (2001). The effect of export assistance program usage on export performance. Journal of International Marketing, 9(2), 51-72.

Gillespie, K., \& Riddle, L. (2004). Export promotion organization emergence and development: Call to research. International Marketing Review, 21(4/5), 465-473.

Gray, B. J. (1997). Profiling managers to improve export promotion targeting. Journal of International Business Studies, Second Quarter, 387-420.

Gronhaug, K., \& Lorentzen, T. (1983). Exploring the impact of governmental export subsidies. European Journal of Marketing, 17(2), 5-12.

Hibbert, E. P. (1990). The management of international trade promotion. London: Routledge.

Hiroshi, Y. (1999). Empirical evidence for export promotion strategies. Applied Economic Letters, 6(12), 775-778.

Johanson, J., \& Vahlne, J. (1977). The internationalization process of the firm - A model of knowledge development and increasing foreign market commitments. Journal of International Business Studies, 8(1), 23-32.

Johanson, J., \& Wiedersheim-Paul, F. (1975). The internationalization of the firm - Four Swedish cases. Journal of Management Studies, 12 , 305-322.

Katsikeas, C., Leonidou, L., \& Morgan, N. (2000). Firm-level export performance assessment: Review, evaluation and development. Journal of the Academy of Marketing Science, 28(4), 493-511.

Katsikeas, C., Piercy, N., \& Ioannidis, C. (1996). Determinants of export performance in a European context. European Journal of Marketing, 30(6), 6-35.

Knowles, L., \& Mathur, I. (1997). The effectiveness of the foreign trade zone as an export promotion program. Policy issues and alternatives. Journal of Macromarketing, Fall, 20-31.

Layard, R. (1974). Cost-benefit analysis (revised ed., p. 64), Penguin Modern Economic Readings.

Lee, W., \& Brasch, J. (1978). The adoption of export as an innovative strategy. Journal of International Business Studies, 9(4), 85-93. 
Lemaghen, F. (1987). A pilot evaluation of the export marketing research scheme, for Richard Young. British Overseas Trade Board, Schanmark Export Marketing Services.

Luostarinen, R., \& Welch, L. (1988). Internationalization: Evolution of a concept. Journal of General Management, Winter, 34-55.

Martin, D. (1996). Japan-based U.S. State Promotional Offices as a form of international contact. Paper presented at the academy of international business, annual meeting. Banff, Canada.

Mayer, C., \& Flynn, J. (1973). Canadian small business abroad: Opportunities, aids and experiences. The Business Quarterly, Winter, 33-45.

Naidu, G. M., \& Rao, T. R. (1993). Public sector promotion of exports: A need-based approach. Journal of Business Research, $27,85-101$.

Olson, H. C. (1975). Studies in export promotion. Stockholm: Almqvist \& Wiksell International.

Onunkwo, I. M., \& Epperson, J. E. (2000). Export demand for U.S. Pecans: Impact of US export promotion programs. Agribusiness, 16(2), $253-265$.

Pahud de Mortanges, C., \& Van Gent, A. P. (1991). International marketing and government export promotion in the Netherlands. Export development and promotion: The role of public organizations, Kluwer Academic Publishers. (pp. 243-271).

Pointon, T. (1978). Measuring the gains from government export promotion. European Journal of Marketing, 12(6), 451-462.

Reid, S. (1984). Information acquisition and export entry decisions in small firms. Journal of Business Research, 12(2), 141-157.

Samiee, S., \& Walters, P. G. P. (1990). Influence of firm size on export planning and performance. Journal of Business Research., $20,235-248$.

Schwarting, U., Thoben, C., \& Wittstock, M. (1982). Nachfrageverhalten Kleiner Und Mittlerer Unternehelmer Nach Aussenhandelsinformationen Und Beratung. Goettingen, Verlag Otto Schwartz \& Co., Beitraege Zur Mittelstandsforschung, Heft 83.

Seringhaus, F. H. R., \& Rosson, P. J. (1998). Management and performance of international trade fair exhibitors: Government stands vs. independent stands. International Marketing Review, 15(5), 398-412.

Seringhaus, F. H. R., \& Rosson, P. J. (1990). Government export promotion: A global perspective. London: Routledge.

Seringhaus, F. H. R., \& Botschen, G. (1991). Cross-national comparison of export promotion services: The views of Canadian and Austrian companies. Journal of International Business Studies, 22(1), 115-134.

Seringhaus, F. H. R., \& Rosson, P. J. (1991). Export development and promotion and public organizations: The state-of-the-art. In F. H. R. Seringhaus \& P. Rosson (Eds.), Export development and promotion: The role of public organizations (pp. 3-19). Norwell, MA: Kluwer Academic Publishers.

Seringhaus, F. H. R., \& Mayer, C. S. (1988). Different approaches to foreign market entry between users and non-users of trade missions. European Journal of Marketing, 22(10), 9-13.

Seringhaus, F. H. R. (1987). The use of trade missions in foreign market entry. Industrial Marketing and Purchasing, 2, 43-60.

Seringhaus, F. H. R. (1986a). The impact of government export marketing assistance. International Marketing Review, 3(2), 61-72.

Seringhaus, F. H. R. (1986b). Empirical investigation of awareness, use and impact of export marketing support by government in manufacturing firms. In Moeller, K., \& Paltschik, M. (Eds.), Contemporary research in marketing (vol. 1, pp. 259-272). Helsinki: European Marketing Academy.

Seringhaus, F. H. R. (1984). Government export marketing assistance \& medium-sized Ontario manufacturing firms: The role \& impact of trade missions on firms off-shore market involvement. PhD dissertation. York University, Toronto.

Singh, N. (1983). Communication and competence in private sector involvement in international trade policy. In M. R. Czinkota (Ed.), Export promotion - The public and private sector interaction (pp. 110-126). New York, NY: Praeger.

Singer, T. O., \& Czinkota, M. R. (1994). Factors associated with effective use of export assistance. Journal of International Marketing, 2(1), 53-71.

Spence, M. M. (2003). Evaluating export promotion programmes: U.K. Overseas trade missions and export performance. Small Business Economics, $20,83-103$.

Suntook, F. (1978). How British industry exports. Marketing (U.K.), June, 29-34.

Walters, P. (1983). Export information sources - A study of their usage and utility. International Marketing Review, 1, 33-43.

Welch, L. S., \& Wiedersheim-Paul, F. (1979). Export promotion policy - A new approach. Australian Journal of Management, 4(October), $165-177$.

Williams, A. (1973). Cost-benefit analysis and cost-effectiveness. Unwin University Books. (p. 58).

Wills, G., \& Oldman, C. (1975). The nature of cost-benefit analysis for information systems. Unpublished paper.

Wilkinson, T. (2006). Entrepreneurial climate and U.S. state foreign trade offices as predictors of export success. Journal of Small Business Management, 44(1), 99-113.

Joan Freixanet has graduated with BBA and MBA in Business Administration from ESADE (Escuela Superior Administración y Dirección de Empresas, UniversitatRamonLlull). The author is the top scorer (sobresaliente cum laude) while pursing Ph.D in Business Administration (Universidad Politécnica de Cataluña) and is working as Professor in International Strategy, ESCI (Escola Superior de Comerç Internacional-UniversitatPompeuFabra). The author has been a consultant for nearly 12 years in International Business and is accredited by different export promotion organizations (ICEX, Chamber of Commerce and ACCIO10) for their consultancy programs. 